\title{
PENGARUH PERSEPSI SISWA ATAS KINERJA GURU \\ DAN MOTIVASI BELAJAR TERHADAP PRESTASI MENULIS BAHASA INDONESIA PADA SISWA SMA SWASTA JAKARTA TIMUR
}

\author{
Tridays Repelita \\ Universitas Buana Perjuangan Karawang \\ Pos-el: tridaysrepelita@yahoo.com \\ HP: 08111007769
}

\begin{abstract}
ABSTRAK
ABSTRAK

Penelitian ini bertujuan untuk memaparkan pengaruh persepsi siswa atas kinerja guru dan motivsi belajar menulis bahasa Indonesia pada SMA swasta Jakarta Timur. Motivasi belajar adalah dorongan pada diri siswa dalam bentuk usaha dan kerja keras guna mencapai prestasi belajar yang lebih baik.Metode yang digunakan dalam penelitian ini adalah penelitian kuantitatif yang bersifat korelasional. Oleh karena itu, peneliti hanya mengungkapkan data berdasarkan hasil pengukuran gejala yang telah ada secara wajar pada responden. Hasil penelittian ini adalah dengan indikator 1)ketekunan belajar, 2)rasa ingin tahu, 3))engerjakan tugas sekolah, 4)rasa ingin berprestasi, dan 5) dan tidak mudah putus asa.
\end{abstract}

Kata kunci: persepsi siswa, kinerja guru, motivasi belajar

\section{ABSTRACT}

This study aims to describe the influence of students' perceptions on teacher performance and motivation to learn to write Indonesian at the private high school in East Jakarta. Motivation to learn is the impetus on students in the form of hard work and efforts in order to achieve better learning achievement baik.Metode used in this research is quantitative correlational research. Therefore, the researchers only disclose data based on measurements of symptoms that already exist naturally in the respondents. The results of this study is the first indicator) perseverance to learn, 2) curiosity, 3) Doing homework 4) flavor to excel, and 5) and not easily discouraged.

\section{Keywords: perceptions of students, teacher performance, motivation to learn}

\section{PENDAHULUAN}

Pascaprogram sertifikasi dosen dijalankan, fenomena tentang kualitas pembelajaran masih banyak dipersoalkan. Pembelajaran yang dimaksud di sini adalah pembelajaran 
bermakna yang mampu menghasilkan output ataupun outcome, berdaya guna tinggi dan mampu bersaing di segala bidang.

Bab XI Pasal 4 Undang-undang No. 20 tahun 2003 tentang Sistem Pendidikan Nasional, Ayat (3) menyebutkan bahwa "Pendidikan diselenggarakan sebagai suatu proses pembudayaan dan pemberdayaan peserta didik yang berlangsung sepanjang hayat". Sementara itu, pada Ayat (4) disebutkan bahwa "Pendidikan diselenggarakan dengan memberi keteledanan, membangun kemauan, dan mengembangkan kreativitas peserta didik dalam proses pembelajaran".

Undang-undang tersebut mengisyaratkan kepada semua pihak untuk bertanggung jawab dan harus segera mempersiapkan suatu langkah perencanaan yang matang demi mengantarkan peserta didik menjadi manusia siap menghadapi segala bentuk tantangan dan hambatan serta memiliki kreasi dan inovasi sepanjang hidupnya sebagai pewaris dan penerus bangsa ini.

Landasan tentang model pembelajaran Unesco menghendaki terjadinya proses pembelajaran bermakna,pembelajaran untuk mengerti (learning to know), pembelajaran untuk bertindak atau berbuat (learning to do),juga menuntut terjadinyapembelajaran untuk membangun jati diri (learning to be), danpembelajaran untuk hidup bersama secara harmonis).

(learning to live together). Fakta yang terjadi di lapangan ternyata kurang menggembirakan, banyak masalah yang harus dihadapi dan diselesaikan ditambah lagi kondisi bangsa yang sedang mengalami krisis multidimensi berdampak buruk bagi dunia pendidikan, khususnya pembelajaran.

Pelajaran bahasa Indonesia merupakan salah satu mata pelajaran yang diujikan secara nasional dan sekaligus sebagai salah satu penentu kelulusan siswa.Mata pelajaran 
ini, meskipun bahasa sendiri, sering ditakuti siswa, bahkan siswa kurang senang, sehingga hasil yang dicapai pun tidak maksimal.

Tentunya, ada berbagai faktor yang dapat berpengaruh terhadap capaian hasil belajar siswa ini. Dari sudut guru, Undang-Undang Nomor 14 tahun 2005 tentang Guru dan Dosen, pasal demi pasal menuntut guru untuk profesional dengan meningkatkan kinerja sehingga guru dapat lulus dalam sertifikasi dan guru akan menikmati penghargaan, tunjangan serta hak yang lebih baik dari sebelumnya.

Data di lapangan menunjukkan bahwa hasil belajar siswa-siswa SMA Perguruan Rakyat Jakarta, untuk mata pelajaran bahasa Indonesia pada semester I Tahun Pelajaran 2012/2013 masih tidak terlalu memuaskan. Skor rata-rata hasil belajar yang didapat siswa masih kurang jika standar ketuntasan yang diharapkan skor yang harus didapat adalah 7,00 .

Hal tersebut mengisyaratkan tentang bagaimana pentingnya dalam mencapai tujuan belajar berupa hasil belajar yang maksimal.Kondisi kinerja mengajar guru yang ada secara tidak langsung berpengaruh pada motivasi belajar siswa, bahkan sangat menentukan apakah siswa merasa bergairah atau tidak bergairah dalam belajar. Ha ini sesuai dengan dan telah diatur dalam standar proses pada Standar Nasional Pendidikan (SNP) Nomor 19 tahun 2005, bahwa guru harus membuat perencanaan pembelajaran, melakukan kegiatan pmebelajaran aktif dan menyenangkan, serta melakukan penilaian pembelajaran Selain kinerja guru, fungsi motivasi dalam proses belajar mengajar meliputi kondisi optimal bagi terjadinya belajar, menggiatkan semangat belajar, menggugah semangat belajar, mengikat perhatian siswa, membantu siswa untuk mendukung pencapaian tujuan belajar.

Motivasi adalah suatu usaha untuk memuaskan kebutuhan-kebutuhan yang menggerakkan individu. Perilaku juga sebagai alat, dengan alat itu individu berusaha untuk memuaskan kebutuhan. Oleh sebab itu, tidak mengherankan dasar untuk memahami 
motivasi terletak pada pemahaman tentang kebutuhan-kebutuhan yang menggerakkan perilaku orang dalam suatu organisasi.

Berdasarkan fakta inilah yang membuat peneliti berkeinginan mengadakan penelitian tentang masalah persepsi siswa terhadap kinerja guru dan motivasi belajar berkaitan dengan hasil belajar siswa, khususnya mata pelajaran bahasa Indonesia pada aspek menulis.

\section{Rumusan Masalah}

Penelitian ini merumuskan masalah sebagai berikut.

1. Apakah terdapat pengaruh persepsi siswa terhadap kinerja guru dan motivasi belajar secara bersama-sama terhadap prestasi menulis siswa pada mata pelajaran bahasa Indonesia aspek menulis?

2. Apakah terdapat pengaruh persepsi siswa terhadap kinerja guru terhadap prestasi menulis siswa pada mata pelajaran bahasa Indonesia aspek menulis?

3. Apakah terdapat pengaruh motivasi belajar terhadap prestasi menulis pada mata pelajaran bahasa Indonesia aspek menulis?

\section{Tujuan Penelitian}

Sesuai dengan rumusan masalah tersebut, tujuan yang ingin dicapai adalah penelitian ini adalah untuk mengetahui

1. pengaruh persepsi siswa terhadap kinerja guru dan motivasi belajar secara bersamasama terhadap prestasi menulis siswa pada mata pelajaran bahasa Indonesia aspek menulis;

2. pengaruh persepsi siswa terhadap kinerja guru terhadap prestasi menulis siswa pada mata pelajaran bahasa Indonesia aspek menulis;

3. pengaruh motivasi belajar terhadap prestasi menulis pada mata pelajaran bahasa Indonesia aspek menulis. 


\section{LANDASAN TEORI}

Hasil belajar yang dicapai siswa merupakan muara dari suatu rangkaian proses pembelajaran yang dilakukan oleh seluruh unsur yang terlibat dalam pendidikan, berupa prestasi yangdicapai oleh siswa, Menurut Nasution (2000: 3) mendefinisakan hasil belajar sebagai hasil yang telah dicapai dalam bentuk perubahan kelakuan anak berdasarkan pengalaman dan latihan”.

Untuk mengetahui hasil belajar siswa harus dilakukan sebuah tes yang jenis dan caranya sangat beragam, ada tes lisan, tes tertulis, tes perbuatan. Djaali (2000: 59) menyatakan bahwa "pengukuran tingkat penguasaan siswa terhadap materi pelajaran dilakukan melalui tes prestasi belajar baik melalui tes baku atau tes buatan guru". Hal ini diperkuat (2001: 79) bahwa "tes prestasi belajar dilihat dari tujuannya yaitu mengungkapkan keberhasilan seseorang dalam belajar".Faktor fisik sangat menentukan keberhasilan belajar, sebagaimana pernyataan Nasution (2000: 42) memberikan petunjuk tentang belajar efektif dan efesien, disebutkan :

"Belajar memerlukan tenaga, karena itu untuk mencapai hasil yang baik diperlukan badan sehat.Anak sakit, kurang makan, kurang tidur atau kurang alat indranya tidak dapat belajar dengan baik (efektif).Kekurangan itu harus ditiadakan dahulu kemungkinan diperlukan bantuan dokter".

Kondisi jiwa anak menurut Arden $\mathrm{N}$ Fransen dalam bukunya "Principles of Learning and Teaching"seperti yang dikutip Suryabrata (2005 : 253) ada 2 hal yang mempengaruhi hasil belajar siswa, yaitu pengaruh positif dan pengaruh negatif.

Arnold (2001: 145) mengatakan bahwa Persepsi adalah "Fungsi psikologis menerima dan mengolah informasi lingkungannya”, sedangkan menurut Vernon (2000: 77) mengatakan bahwa "Persepsi sebagai ingatan dan pengorganisasian pengalaman-pengalaman sensory". Dua pendapat tersebut merupakan pendapat yang saling berkaitan dengan menekankan 
bahwa persepsi muncul setelah seseorang menerima pengalaman-pengalaman yang didapatkan dari lingkungan yang kemudian diolah melalui sensor motoriknya.

Sejalan pula dengan pendapat di atas, Bimo Walgito, mengatakan bahwa persepsi adalah "Proses rangsangan dari luar melalui alat penginderaan kita teruskan ke pusat otak kemudian ditafsirkan adalah merupakan persepsi”, sementaramenurut Kemp dan Dayton, menyatakan bahwa "Persepsi sebagai suatu proses anggapan yakni seseorang menyadari keberadaan lingkungannya serta dunia yang mengelilinginya". Selanjutnya Thantowi R. mengemukakan bahwa "Persepsi adalah proses mengingat atau mengidentifikasi sesuatu objek atau peristiwa-peristiwa objektif dengan menggunakan pengertian”. Dalam hal yang sama, Siagian berpendapat bahwa "Persepsi merupakan proses penataan dan penerjemahan kesan-kesan ataupun cara pandang seseorang di dalam menginterpretasikan suatu lingkungan sebagai suatu kenyataan" ( Siagian, 2001: 189), sedangkan menurut Rahmat (2000: 81) mengemukakan bahwa "Persepsi adalah pengalaman tentang objek, peristiwa, atau hubungan-hubungan yang diperoleh dengan menyimpulkan informasi dan mentafsirkan pesan (sensori stimuli)".

Dengan demikian persepsi merupakan proses penafsiran pesan yang diterima dan diinterpretasikan ke dalam suatu kenyataan. Pendapat lain dikemukakan oleh Suryobroto (2003: 94) mengatakan bahwa "Individu yang tergabung dalam suatu kelompok mempunyai gambaran akan kebiasaan kelompoknya, tingkah laku, nilai-nilai kelompok yang diikuti, dan membanding-bandingkan dengan kebiasaan dan nilai-nilai dari kelompok lain yang dimunculkan dalam persepsi”. Mendukung pendapat tersebut disampaikan oleh Prawiradilaga (2004: 103), yang menyatakan bahwa "Persepsi adalah awal dari segala macam kegiatan belajar yang bisa terjadi pada setiap kesempatan, disengaja atau tidak". Fleming dan Levie mempercayai persepsi sebagai suatu proses penerimaan informasi yang rumit, yang diterima atau diekstraksi manusia dari lingkungan. 
Menurut Wibawa (2003) performan adalah "Unjuk kerja berupa tingkah laku yang nampak dan merupakan prestasi kerja atau hasil kerja”.Menurut Nickols (1977) Defines performance as " The outcome of behavior, Behavior is individual activity whereas the outcomes of behavior are the waysinwhichthebehavingindividual'senvironment is somehow different as a result of his or her behavior. Sedangkan menurut Gilbert (1974) "in the same vein, equates perforceman with "accomplishments" that we value”.

Maksudnya adalah kinerja menjadi suatu ukuran keberhasilan aktivitas individu di lingkungannya. Sedangkan menurut kamus besar bahasa Indonesia kinerja diartikan sebagai kemampuan kerja atau kompetensi kerja yang dimiliki oleh seseorang sesuai pekerjaannya atau profesinya, menurut Anwar Prabu (2000) memberikan pengertian kinerja yaitu: "Kinerja sebagai prestasi kerja atau hasil kerja secara kualitas dan kuantitas yang dicapai seorang pegawai dalam melaksanakan tugasnya sesuai dengan tanggung jawab yang diberikan kepadanya".

Demikian pula seperti dikatakan oleh Bernandin dan Russel (dalam Sianipar,2000), "kinerja adalah hasil dari fungsi pekerjaan atau kegiatan tertentu".

Di Negara kita, profesi guru berkembang mulai dari zaman K. H. Ahmad Dahlan, Asy Arie, Soekarno dan Ki Hajar Dewantara hingga kini profesi guru cenderung mengalami perubahan bahwa guru merupakan profesi yang dari hasil kerjanya mendapatkan hasil dan dihargai baik materi yang harus cukup atau kepuasan hati nurani, jika para anak didiknya menjadi manusia yang berhasil. Guru adalah sebutan bagi tenaga pendidik atau pengajar yang bertugas pada satuan pendidikan dasar dan menengah. Di dalam Undang-Undang Sisdiknas Tahun 2003 disebutkan bahwa Guru adalah "Pendidik yang harus memiliki kualifikasi minimum dan memiliki sertifikasi sesuai dengan jenjang kewenangan mengajar, sehat jasmani dan rohani, memiliki kemampuan dalam mewujudkan tujuan pendidikan nasional". 
Kinerja merupakan nilai dari seperangkat perilaku yang berkontribusi baik secara positif maupun negatif terhadap pencapaian tujuan organisasi.Artinya kinerja positif akan berkontribusi pada semakin tercapaianya tujuan organisasi, dan semakin negatif kinerja, maka akan berpengaruh terhadap semakin jauh pencapaian tujuan, seperti dikatakan "Job performance is formally defined as the value of the set of employee behaviors that contribute, either positively or negatively, to organizational goal accomplishment". (Jasson A. Colquitt, et.al, 2009: 37)

Danielson (dalam Sergiovanni dan Starra, 2002: 183--185) menggambarkan kinerja guru dalam 4 domain level kinerja, yaitu : Persiapan dan perencanaan, lingkungan kelas, pelaksanaan pembelajaran, dan tanggungjawab profesi.

Menurut Lang \& Evans (2006 : 298) bahwa kegiatan mengajar dimulai dengan beberapa tahapan berikut.

"Pertama berupa perencanaan sebelum kegiatan pembelajaran dimulai, tahap kedua adalah menjelaskan tujuan pembelajaran yang dikaitkan dengan apa yang telah dipelajari sebelumnya dan yang akan dipelajari berikutnya, tahap ketiga adalah menyajikan dan mengorganisasi kemajuan belajar yang dapat meningkatkan pemahaman dan daya ingat terhadap materi yang telah diajarkan, tahap keempat adalah melibatkan dan memotivasi belajar siswa dengan memberikan penjelasan yang disertai contoh-contoh sehingga membantu mereka untuk memahami pelajaran, tahap kelima adalah memberikan kesempatan kepada siswa untuk mengulang dan mempraktekkan pelajaran yang telah lalu sehingga ada penguatan atas apa yang mereka dapatkan, dan tahap terakhir adalah pemberian tes untuk mengetahui seberapa baik pemahaman siswa terhadap pelajaran". 
Menurut . Lunenburg dan Irby (2006: 88--89) konten perencanaan pembelajaran, dan keterampilan teknis yang harus dikuasai adalah keterampilan khusus sehingga tujuan dapat tercapai dengan baik. Di iantara keterampilan itu adalah: ketrampilan bertanya (question skill), ketrampilan memberi penguatan (reinforscement skills), keterampilan mengadakan variasi (variation skills), ketrampilan menjelaskan (exsplanation skills), ketrampilan membuka dan menutup pelajaran (set induction and closure), ketrampilan membimbing diskusi kelompok kecil, ketrampilan mengelola kelas, dan Ketrampilan mengajar perseorangan (Usman, 1992: 66).

Wilson (1999: 158) menggambarkan pengukuran kinerja dengan tujuh macam metode, yaitu: penilaian kinerja yang dilakukan oleh atasan langsung, penilaian oleh diri sendiri, penilaian oleh bawahan, penilaian oleh teman sejawat, penialaian secara tim, dan penilaianumpan balik 360 derajat yang berfokus pada pengembangan skill.

Sehubungan dengan motivasi, Usman (2006: 115) menyatakan: "Motivasi adalah suatu proses menggiatkan motif-motif menjadi perbuatan atau tingkah laku untuk memenuhi kebutuhan untuk mencapai tujuan atau kesiapan dalam diri individu yang mendorong tingkah lakunya untuk berbuat sesuatu dalam mencapai tujuan tertentu".

Donald dalam Hamalik (2001: 75) menyatakan bahwa: "Motivasi adalah suatu perbedaan energi dalam diri seseorang yang ditandai dengan timbulnya perasaan dan reaksi untuk mencapai tujuan".

Dimyati dan Mulyono (2002: 83) mengemukakan bahwa siswa belajar karena didorong oleh kekuatan mentalnya. Kekuatan mental itu berupa keinginan, perhatian, kemauan, atau cita-cita. Kekuatan mental tersebut dapat tergolong rendah atau tinggi. Ada ahli psikologi pendidikan yang menyebut kekuatan mental yang mendorong terjadinya belajar tersebut sebagai motivasi belajar. Motivasi dipandang sebagai dorongan mental yang menggerakkan dan mengarahkan perilaku manusia, termasuk perilaku belajar. 
NL. Gage dan David C. Berliner (1977) mengemukakan "Motivation is the term used to describe what energizes a person and what direct his activity”.

Berhubungan dengan motivasi belajar itu pula Worrel dan Stiwel (dalam Winaputra, 1996) “adanya motivasi dapat disimpulkan dari suatu observasi". Siswa akan memperlihatkan minat, mempunyai perhatian, dan ingin ikut serta meluangkan waktu dan berusaha keras untuk menyelesaikan tugas. Memperkuat pendapat-pendapat lain yang berhubungan dengan motivasi belajar berikut ini antara lain :

Dick and Carey (2001: 113) mengatakan "Motivation level of learnes the most important faktor in successful instruction”. Sedangkan menurut Jhon Keller (1987) menyatakan "In order produce instruction the motivates the learn, these four attributes of the instruction, the first aspect of motivation is to gain the attention of learnes and subsequently sustain it throughout the instruction. Student must attend to a task in order to learn perform it. The second aspect of motivation is relevance information and context analyses to help learnes understand the relevance of the skill included in instruction, the third, they must confident that they can master objectives for instruction, the final model is satisfaction. High motivation depends onwether learner ferives satisfaction form learning experience”.

Maksudnya adalah motivasi merupakan aspek pendukung dalam kesuksesan mencapai tujuan belajar, membantu siswa untuk memahami keterampilan, menambah percaya diri dalam belajar dan uji coba yang dilakukan siswa. Mc. Lelland (1974) mengemukakan bahwa "Motivasi yang ada pada diri manusia yang kehidupannya berbeda dengan kebutuhan yang harus dipenuhi pada manusia itu sendiri”, sementara menurut Winkel (1983: 68) mengatakan bahwa "Motivasi belajar adalah keseluruhan daya 
penggerak di dalam diri siswa yang menimbulkan kebiasaan belajar yang menjamin kelangsungan kebiasaan belajar memberikan arah pada kegiatan itu, maka keinginan yang dikehendaki oleh siswa tercapai".

Pranoto (1981) berpendapat bahwa "Fungsi motivasi dalam proses belajar mengajar meliputi kondisi optimal bagi terjadinya belajar, menggiatkan semangat belajar, menggugah semangat belajar, mengikat perhatian siswa, membantu siswa untuk mendukung pencapaian tujuan belajar" dan Kenneth (dalam Hamalik, 2001) mengemukakan prinsip-prinsip motivasi belajar sebagai berikut.

1) Pujian lebih efektif dari hukuman;

2) Kebutuhan psikologis mendasar agar dipuaskan;

3) Motivasi intrinsik lebih baik dari ekstrinsik;

4) Pemberian penguatan terhadap tingkah laku;

5) Pemahaman yang jelas terhadap tujuan akan merangsang motivasi belajar;

6) Membebankan tugas untuk diri sendiri lebih efektif daripada tugas yang diberikan orang lain;

7) Ganjaran yang berasal dari luar kadang-kadang diperlukan dan cukup efektif untuk merangsang diri sendiri.

Berdasarkan uraian di atas, dapat disimpulkan bahwa motivasi belajar adalah dorongan pada diri siswa dalam bentuk usaha dan kerja keras guna mencapai prestasi belajar yang lebih baik dengan indikator: (1)ketekunan belajar, (2)rasa ingin tahu, (3)mengerjakan tugas sekolah, (4)rasa ingin berprestasi, dan (5)tidak mudah putus asa. 


\section{METODE PENELITIAN}

Penelitian tentang hubungan antara persepsi siswa terhadap kinerja guru dan motivasi belajar dengan hasil belajar siswa ini dilakukan di SMA Perguruan Rakyat Jakarta.Sedangkan waktunya dimulai bulan Oktober sampai dengan Desember 2013.

Penelitian ini merupakan penelitian kuantitatif yang bersifat korelasional karena tidak memberikan perlakuan apapun terhadap subjek penelitian, peneliti hanya mengungkapkan data berdasarkanhasil pengukuran gejala yang telah ada secara wajar pada responden, dengan alat pengumpul data kuesioner dan dokumentasi, sedangkan sifat korelasional dimaksudkan untuk mencari hubungan antar variabel.

Arikunto (2002:55) menyatakan bahwa penelitian korelasi adalah suatu alat statistik yang dapat digunakan untuk membandingkan hasil pengukuran dua variabel yang berbeda agar dapat menentukan hubungan antara variabel-variabel”. Metode yang digunakan dalam penelitian ini adalah survei, yaitu penelitian dengan teknik mendatangi langsung subjek penelitian yaitu responden yang merupakan sampel penelitian untuk mendapatkan data yang dibutuhkan.

Pada pelaksanaan penelitian akan selalu berhadapan dengan objek yang diteliti baik berupa manusia, benda, peristiwa maupun gejala yang terjadi. Objek tersebut disebut populasi.Populasi adalah totalitas semua nilai yang mungkin, hasil menghitung atau pengukuran, kualitatif maupun kuantitatif mengenai karakteristik tertentu dari semua anggota yang lengkap dan jelas yang ingin dipelajari sifat-sifatnya. Sedangkan sampel adalah sebagian dari jumlah dan karakteristik yang dimiliki oleh populasi. Populasi dalam penelitian ini adalah seluruh siswa SMA Perguruan Rakyat Jakarta, sedangkan sampelnya diambil sebanyak 50 orang siswa kelas XI dengan menggunakan teknik proportionalrandom sampling.Jumlah sampel di atas selanjutnya menjadi responden dalam penelitian ini sekaligus sebagai sumber data yang mengisi instrumen penelitian, 
yakni instrumen persepsi siswa terhadap kinerja guru, instrumen motivasi belajar, dan tes hasil belajar bahasa Indonesia.

Variabel penelitian ini terdiri dari dua variabel bebas dan satu variabel terikat, yaitu persepsi siswa terhadap kinerja guru (X-1) dan motivasi belajar (X-2) sebagai variabel bebas dan hasil belajar (Y)sebagai variabel terikatnya.

1. Variabel hasil belajar

a) Definisi konseptual

Hasil belajar siswa pada mata pelajaran bahasa Indonesia adalah perolehan prestasi yang dicapai siswa sebagai akibat dari proses belajar yang dilakukannya melalui bantuan dan dukungan guru serta faktor lainnya, dengan indikator 1)penggunaan tata bahasa Indonesia, 2)penempatan tanda baca, dan 3)kejelasan isi tulisan.

b) Definisi operasional

Hasil belajar siswa pada mata pelajaran bahasa Indonesia adalah skor perolehan siswa atas jawaban yang diberikan pada tes keterampilan menulis bahasa Indonesia, dengan indikator 1. Penggunaan tata bahasa Indonesia, 2.Penempatan tanda baca, dan 3.Kejelasan isi tulisan.

\section{HASIL DAN PEMBAHASAN}

Pengaruh Persepsi Siswa terhadap Kinerja Guru dan motivasi belajar terhadap Prestasi Menulis Siswa.

Hasil belajar siswa merupakan variabel yang tidak dapat berdiri sendiri. Akan tetapi, merupakan dampak dari variabel lain yang mempengaruhinya seperti motivasi, minat, lingkungan, kinerja guru, dan ketersediaan sarana prasarana. 
Ranah hasil belajar sebagai akibat dari proses belajar dapat dilihat dari aspek kognitif berupa kemampuan nalar keilmuan siswa dalam memahami mater plejaran, aspek afektif berupa sikap dan perilaku dalam kegiatan sehari-hari, dan aspek psikomotorik berupa keterampilan fisik berupa keahlian pada bidang tertentu.

Persepsi terhadap kinerja guru merupakan penilaian siswa terhadap apa yang dilihat dan diperhatikannya terhadap perilaku kerja guru dalam mengajar, sedangkan motivasi belajar adalah dorongan internal dalam diri siswa untuk mengikuti kegiatan belajar mengajar di sekolah. Kedua variabel tersebut merupakan variabel yang berkaitan erat dengan hasil yang dicapai siswa karena merupakan satu kesatuan yang tidak dapat dipisahkan.

Siswa yang memiliki persepsi positif terhadap kinerja guru dalam mengajar dan memiliki motivasi belajar tinggi cenderung memiliki hasil belajar yang tinggi pula. Dengan demikian, diduga terdapat hubungan positif antara persepsi siswa terhadap kinerja guru dan motivasi belajar siswa dengan hasil belajar siswa. Artinya, semakin positif persepsi siswa terhadap kinerja guru dan semakin tinggi motivasi belajar siswa maka akan semakin tinggi prestasi belajar mereka.

\section{Pengaruh Persepsi Siswa terhadap Kinerja Guru terhadap Prestasi Menulis Siswa}

Persepsi siswa terhadap kinerja guru merupakan tanggapan yang diberikan siswa terhadap kemampuan kerja guru yang ditunjukkan melalui penampilan dan proses mengajar seorang guru. Sesuai dengan standar pendididkan, guru dituntut untuk melakukan tugas yang baik dan juga mendapatkan hasil yang sesuai namun dalam hal ini kinerja tersebut diperlukan tanggapan dari semua pihak.

Guru sebagai model sekaligus fasilitator dalam yang melakukan pembimbingan kepada siswa untuk dapat mengikuti proses belajar mengajar dengan tertib, nyaman, dan menyenangkan. Dalam rangka itu, kreativitas guru dalam menyampaikan materi pelajaran 
dengan menggunakan berbagai macam pendekatan dan model pembelaaran yang interaktif sehingga siswa merasa puas mengikuti proses pembelajaran.

Kondisi psikologi siswa yang senang dan nyaman dalam pembelajaran berakibat pada munculnya berpersepsi terhadap guru yang mengajarnya.Akhirnya berdampak pada pencapaian hasil belajar siswa berupa skor atau nilai yang baik.

Berdasarkan pemikiran di atas, diduga terdapat pengaruh persepsi siswa terhadap kinerja guru terhadap hasil belajar siswa, artinya semakin positif persepsi siswa terhadap kinerja guru maka akan semakin tinggi hasil belajar yang dicapai siswa.

\section{Pengaruh Motivasi Belajar terhadap Prestasi Menulis Siswa}

Motivasi merupakan dorongan yang ada dalam diri setiap individu karena harapan, keinginan dan pemenuhan kebutuhan yang diinginkannya. Seorang siswa yang memiliki motivasi belajar tinggi dapat dilihat dari cara mereka belajar, intensitas belajar, ketekunan dalam belajar, serta kekuatan menghadapi kendala dan persoalan dalam pembelajaran.

Dukungan motivasi dalam belajar menentukan bagaimana siswa melakukan aktivitas belajarnya. Motivasi belajar siswa bisa bersumber dari internal artinya berupa dorongan dari diri siswa dalam bentuk keinginan, harapan dan tujuan yang hendak dicapai. Sementara itu, sumber eksternal bisa berasal dari dukungan orang tua, guru, dan lingkungan belajar yang kondusif.

Siswa yang memiliki motivasi belajar tinggi cenderung melakukan aktivitas belajar tinggi pula sehingga bisa berdampak pada pencapaian hasil belajar yang optimal. Sehubungan dengan itu, diduga terdapat pengaruh motivasi belajar terhadap hasil belajar siswa. Artinya, semakin tinggi motivasi belajar maka akan semakin tinggi pula hasil belajar siswa. 
3. Variabel Motivasi Belajar

a) Definisi konseptual

Motivasi belajar adalah dorongan pada diri siswa dalam bentuk usaha dan kerja keras guna mencapai prestasi belajar yang lebih baik dengan indikator: 1. Ketekunan belajar, 2. Rasa ingin tahu, 3. Mengerjakan tugas sekolah, 4. Rasa ingin berprestasi, dan 5. Tidak mudah putus asa.

b) Definisi operasional

Motivasi belajar adalah skor jawaban siswa atas instrumen yang mengukur motivasi belajar dengan indikator: 1. Ketekunan belajar, 2. Rasa ingin tahu, 3. Mengerjakan tugas sekolah, 4. Rasa ingin berprestasi, dan 5. Tidak mudah putus asa.

c) Kisi-kisi instrumen

\section{Tabel 1 Kisi-Kisi Instrumen Motivasi Belajar}

\begin{tabular}{|l|l|l|}
\hline $\begin{array}{l}\text { Variabel } \\
\text { Penelitian }\end{array}$ & Indikator & Nomor Butir \\
\hline Motivasi belajar & $\begin{array}{l}\text { 1.Ketekunan belajar } \\
\text { 2.Rasa ingin tahu }\end{array}$ & $1,2,3,4,5$ \\
& $\begin{array}{c}\text { 3.Mengerjakantugassekol } \\
\text { ah }\end{array}$ & $11,12,13,14,15$ \\
& $\begin{array}{c}\text { 4.Rasa ingin berprestasi } \\
\text { 5.Tidak mudah putus asa }\end{array}$ & \\
\hline
\end{tabular}




\begin{tabular}{|l|l|l|}
\hline & & $16,17,18,19,20$ \\
& & 21,22 \\
& & $23,24,25$ \\
\hline & Jumlah & 25 butir \\
\hline
\end{tabular}

d) Validitas Butir Instrumen

Validitas instrumen adalah ketepatan dari suatu instrumen atau alat pengukur terhadap konsep yang kan diukur. Dengan demikian, suatu instrumen akan memiliki validitas yang baik, jika betul-betul mengukur apa yang hendak diukur dengan cara mengelompokkan soal bernomor ganjil dan diberi symbol $\mathrm{X}$ dan soal yang bernomor genap diberi symbol Y, kemudian diuji dengan rumus korelasi product moment sebagai berikut.

$$
\mathrm{r}_{\mathrm{xy}}=\frac{\mathrm{N} \Sigma \mathrm{XY}-(\Sigma \mathrm{X})(\Sigma \mathrm{Y})}{\sqrt{\left\{\mathrm{N} \Sigma \mathrm{X}^{2}-\left(\Sigma \mathrm{X}^{2}\right)\right\}\left(\mathrm{N} \Sigma \mathrm{Y}^{2}-\left(\Sigma \mathrm{Y}^{2}\right)\right\}}}
$$

Keterangan:

$r_{x y}=$ Koefisien korelasi antara $\mathrm{x}$ dan $\mathrm{y}$

$\mathrm{N}=$ Jumlah sampel

$X=$ soal bernomor ganjil

$\mathrm{Y}=$ soal bernomor genap 
Selanjutnya, untuk menginterpretasikan koefisien korelasi yang didapat dilakukan dengan menggunakan pendapat Masrun yang menyatakan bahwa butir yang memiliki korelasi positif dengan skor total serta korelasi tinggi, menunjukkan bahwa butir tersebut mempunyai validitas tinggi.Berdasarkan ketentuan, apabila butir pertanyaan kuesioner setelah dihitung dengan rumus korelasi product moment dengan menggunakan proses perhitungan dari computer program Microsoft Excel dengan kriteria uji $\mathrm{r}$ hitung $>\mathrm{r}$ tabel $(\alpha=0,05)$ maka butir soal adalah valid dan sebaliknya uji $\mathrm{r}$ hitung $<\mathrm{r}$ tabel $(\alpha=0,05)$ maka butir soal adalah tidak valid (drop).

e) Reliabilitas Butir Instrumen

Reliabilitas adalah ketepatan atau keajegan alat ukur dalam mengukur apa yang diukur. Artinya instrumen alat ukur tersebut kapan pun akan digunakan memberikan hasil ukuran yang sama. Reliabilitas juga menunjukkan suatu pengertian bahwa suatu instrumen tersebut sudah baik atau dapat memberikan hasil yang tepat. Tingkat reliabilitas kuesioner dengan menggunakan teknik Cronbach Alpha $(\alpha)$ sebagai berikut :

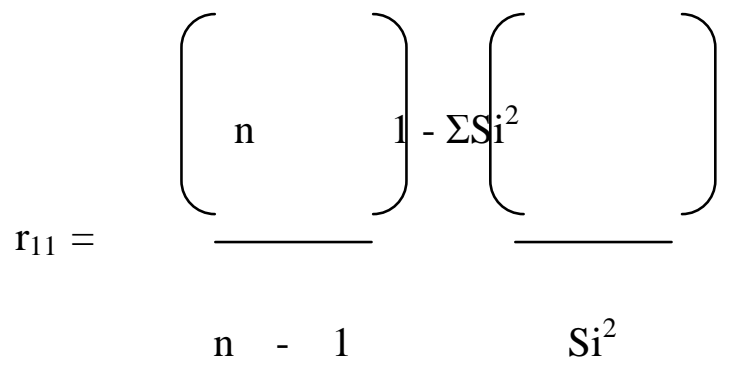

\section{Keterangan :}

$\mathrm{r}_{11}=$ koefisien tes yang dicari

$\Sigma \mathrm{Si}^{2}=$ jumlah varians skor tiap-tiap butir soal 


$$
\begin{array}{ll}
\mathrm{Si}^{2} & =\text { varians skor total } \\
\mathrm{n} & =\text { banyak butir soal }
\end{array}
$$

Klasifikasi nilai koefisien reliabilitas didasarkan pendapat Arikunto (1998) yaitu:

$$
\begin{array}{ll}
0,81-1,00 & =\text { sangat tinggi } \\
0,61-0,80 & =\text { tinggi } \\
0,41-0,60 & =\text { cukup } \\
0,21-0,40 & =\text { rendah } \\
0,00-0,20 & =\text { sangat rendah }
\end{array}
$$

\section{Teknik Pengumpulan data}

Untuk mengumpulkan data dalam penelitian ini digunakan dua teknik pengumpulan data yaitu kuesioner atau angket model Skala Likert dengan 5 pilihan jawaban. Kuesioner dipakai untuk pengambilan data persepsi siswa terhadap kinerja guru dan motivasi belajar, sedangkan hasil belajar siswa pada mata pelajaran bahasa Indonesia aspek menulis diberikan dalam bentuk tes kinerja.

Kuesioner dikembangkan berdasarkan kisi-kisi variabel persepsi siswa terhadap kinerja guru yang disesuaikan dengan kemampuan siswa dalam memberikan tanggapan, yang isinya berkisar dari aktivitas guru dalam perencanaan, pelaksanaan, evaluasi pembelajaran, dan interaksi dalam pembelajaran, variabel motivasi belajar yang berkisar usaha, sikap dan keinginan untuk berprestasi, dan variabel hasil belajar yang berkisar tentang kemampuan siswa dalam menulis sebuah naskah. 
Dari kisi-kisi tersebut selanjutnya dibuatlah instrumen kuesioner persepsi siswa terhadap kinerja guru dan motivasi belajar yang disebarkan kepada siswa untuk kemudian diskor dengan kriteria skor untuk siswa memilih jawaban (a) diberi skor 5, (b) skor 4, (c) skor 3, (d) skor 2, dan (e) skor 1 untuk butir positif, sedangkan untuk butir negatif dibali dari skor 1 sampai 5.

\section{Teknik Analisis Data}

Teknik analisis data penulis menggunakan bantuan perhitungan Statistik yaitu SPSS 16, yaitu untuk menganalisis data sebagai berikut:

1. Teknik analisis data deskriptif

Setelah data terkumpul maka langkah berikutnya adalah mengolah dan menganalisis data ke dalam table dan dilengkapi dengan grafik serta perhitungan rata-rata, median, modus dan standar deviasi.

2. Uji Persyaratan Analisis

a) Uji Normalitas

Uji normalitas dimaksudkan untuk memperlihatkan bahwa data sample berasal dari populasi yang berdistribusi normal. Pada analisis regresi persyaratan analisis yang dibutuhkan adalah bahwa galat regresi untuk setiap pengelompokkan berdasarkan variabel terikatnya berdistribusi normal.

Pengujian kenormalan dilakukan dengan menggunakan statistik Kolmogorov-Smirnov yang apabila taraf signifikansi lebih besar dari taraf signifikan uji maka sample berasal dari populasi berdistribusi normal sedangkan apabila taraf signifikansi lebih kecil dari taraf signifikan uji maka sample tidak berasal dari populasi berdistribusi normal. 
Ho : Sampel berasal dari populasi berdistribusi normal

H1 : Sampel tidak berasal dari populasi berdistribusi normal

b) Uji Linieritas

Uji linieritas dimaksudkan untuk memperlihatkan bahwa dua atau lebih kelompok data sampel berasal dari pola yang linier atau bergaris lurus tingkat kenaikannya.

Dengan ketentuan jika taraf signifikan yang didapat besar dari taraf signifikan uji $(0,05)$ maka data setiap sampel sama berbntuk linier sebaliknya jika taraf signifikan yang didapat lebih kecil dari taraf signifikan uji $(0,05)$ maka maka data berbentuk tidak linier.

c) Uji multikolinieritas dan heterodastisitas

Uji multikolinieritas dan heterodastisitas dilakukan untuk mengetahui bahwa data variabel bebas tidak terjadi hubungan yang berarti.

3. Pengujian hipotesis

Analisis data untuk menguji hipotesis menggunakan regresi linier dibantu dengan piranti lunak berupa program SPSS versi 16,00. Hipotesis pertama menggunakan regresi berganda sedangkan hipotesis kedua dan ketiga menggunakan regresi sederhana.

Sedangkan untuk menguji hipotesis diuji dengan analisis varian (Uji F) dengan kriteria uji jika nilai signifikan (sig < 0,05, maka Ho ditolak dan H1 diterima, artinya ada hubungan antara dua variabel yang diuji. Sedangkan untuk melihat besarnya kontribusi dapat dilihat besarnya koefisien determinasi $\left(\mathrm{R}^{2}\right)$.

Selanjutnya untuk mengukur tingkat hubungan persepsi siswa tentang kinerja guru dan motivasi belajar terhadap hasil belajar Kimia maka teknik analisis 
data yang digunakan adalah regresi linier dan korelasional dengan alas an memilih teknik, karena teknik dapat memberikan gambaran tentang hubungan antara satu variabel dengan beberapa variabel yang ditelitinya.

Untuk menyelesaikan perhitungan analisis regresi tersebut di atas dilakukan dengan cara eliminasi dan menggunakan program SPSS, sehingga diperoleh persamaan garis regresi $\mathrm{Y}=\mathrm{ao}+\mathrm{a} 1 \mathrm{X} 1+\mathrm{a} 2 \mathrm{X} 2$.

Untuk menginterpretasikan besar kecilnya koefisien korelasi antara variabel bebas dengan variabel terikat disesuaikan dengan standar bawah ini :

\section{Tabel 2 Kriteria Nilai Koefisien Korelasi}

\begin{tabular}{|l|l|}
\hline $\begin{array}{l}\text { Interval Koefisien } \\
\text { Korelasi }\end{array}$ & Tingkat Kesukaran \\
\hline $0,80-1,00$ & Korelasi sangat kuat atau sempurna \\
\hline $0,50-0,79$ & Korelasi kuat \\
\hline $0,40-0,59$ & Korelasi sedang \\
\hline $0,20-0,39$ & Korelasi rendah \\
\hline $0,00-0,19$ & Tidak ada korelasi atau korelasi rendah \\
\hline
\end{tabular}

\section{Hipotesis Statistik}

Berdasarkan teknik analisis di atas, maka dapat dikemukakan hipotesis statistiknya sebagai berikut: 
1. Ho : $\beta_{1}=\beta_{2}=0$

$\mathrm{H} 1: \beta_{1} \neq \beta_{2} \neq 0$

2. Ho : $\beta_{1}=0$

$\mathrm{H} 1: \beta_{2} \neq 0$

3. Ho $: \beta_{2}=0$

$\mathrm{H} 1: \beta_{2} \neq 0$

\section{HASIL DAN PEMBAHASAN}

\section{Deskripsi Data}

Deskripsi data menampilkan hasil analisisdata penelitian secara statistik deskriptif dan inferensial dari hasil perhitungan dan pengujian yang dilakukan dengan bantuan komputer melalui program aplikasi SPSS 16. Hasil analisis dan intepretasi dapat dilihat pada tabel sebagai berikut.

Tabel 3 Deskripsi Data Penelitian

\begin{tabular}{|c|c|c|c|}
\hline & $\mathrm{X} 1$ & $\mathrm{X} 2$ & $\mathrm{Y}$ \\
\hline valid & 50 & 50 & 50 \\
\hline mean & 86.3400 & 98.9800 & 84.1600 \\
\hline median & 85.5000 & 98.5000 & 84.5000 \\
\hline mode & 85.00 & 98.00 & $84.00^{\mathrm{a}}$ \\
\hline
\end{tabular}




\begin{tabular}{|l|l|l|l|} 
std. deviation & 9.15760 & 9.23279 & 5.67256 \\
variance & 83.862 & 85.244 & 32.178 \\
skewness & -.148 & -.398 & -.547 \\
std. error of skewness & -337 & .337 & .337 \\
kurtosis & -.749 & -.275 & -.202 \\
std. error of kurtosis & 362 & .662 & .662 \\
range & 67.00 & 78.00 & 70.00 \\
minimum & 103.00 & 116.00 & 93.00 \\
maximum & 4317.00 & 4949.00 & 4208.00 \\
\hline
\end{tabular}

\section{Analisis Data Variabel Persepsi Siswa terhadap Kinerja Guru $\left(\mathbf{X}_{1}\right)$}

Skor persepsi siswa terhadap kinerja guru yang diperoleh dari para responden mempunyai rata-rata 86,34dengan simpangan baku 9,15, median sebesar 85,50, modus 85,00 , skor minimum 67 dan skor maksimum 103. Banyaknya butir pertanyaan yang valid dalam instrumen persepsi siswa terhadap kinerja guru adalah 23 butir sehingga skor teoritik minimal 23 dan maksimal 115. 
Hasil penelitian diperoleh skor rata-rata 86,34 dengan skor maksimum tiap butir pertanyaan adalah 5, maka skor rata-rata tiap pertanyaan adalah 3.75.hal ini menunjukkan bahwa rata-rata skor persepsi responden atas kinerja guru termasuk tinggi. Skor simpangan baku 9,15dari rata-rata, menunjukkan perbedaan jawaban antarresponden termasuk rendah. Dengan demikian, persepsi siswa terhadap kinerja guru dari jawaban responden yang diperoleh dalam penelitian tidak terlalu beragam.

Dari deskripsi data penelitian di atas, dapat dilihat bahwa antara nilai rata-rata dan median hampir sama, yaitu berkisar 86,34dan 85,50. Hal ini menunjukkan bahwa data skor persepsi siswa terhadap kinerja guru pada penelitian ini cukup representatif karena data cenderung memusat, sedangkan histogram yang menggambarkan sebaran dari data tersebut bisa dilihat pada gambar sebagai berikut.

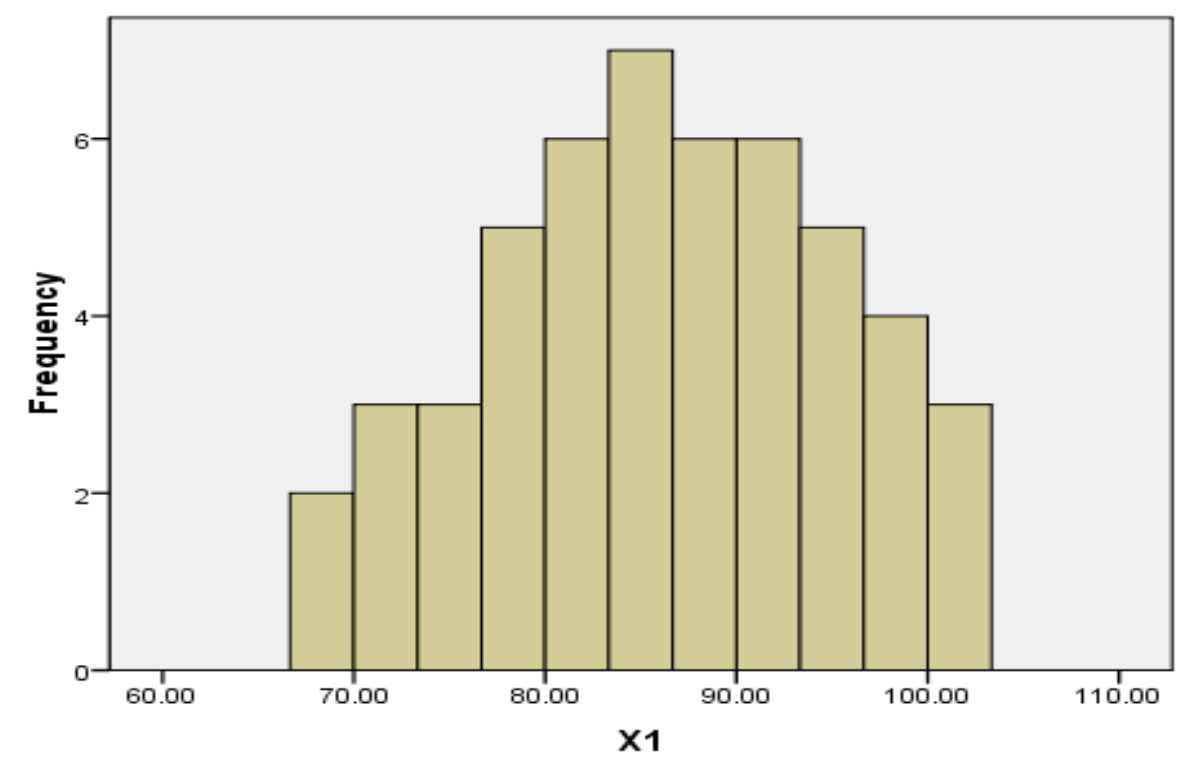

Gambar 1 Histogram Data Skor Persepsi Siswa Terhadap Kinerja Guru 
Dari tabel distribusi frekuensi dan histogram di atas, dapat disimpulkan bahwa data skor persepsi siswa terhadap kinerja guru dalam penelitian ini memiliki sebaran yang cukup baik karena cenderung membentuk kurva normal.

\section{Analisis Data Motivasi Belajar Siswa $\left(\mathbf{X}_{2}\right)$}

Skor motivasi belajar siswa yang diperoleh dari para responden mempunyai ratarata 98,98dengan simpangan baku 9,23, median 98,50, modus 98,00, skor minimum 78 dan skor maksimum 116. Banyaknya butir pertanyaan yang valid dalam instrumen ini adalah 25 butir dengan skor maksimum tiap butir pertanyaan adalah 5, maka skor rata-rata tiap pertanyaan adalah 3,95 . Hal ini menunjukkan bahwa rata-rata motivasi belajar siswa yang menjadi responden termasuk tinggi. Skor simpangan baku 9,23dari rata-rata, menunjukkan perbedaan jawaban antar responden termasuk sedang. Dengan demikian, data skor motivasi belajar siswadari responden cukup beragam.

Deskripsi tersebut dapat dilihat bahwa antara meandan danmedianhampir sama, yaitu 98,98dan 98,50menunjukkan bahwa data skor motivasi belajar siswayang diperoleh pada penelitian ini cukup representatif. Hal itu dikarenakan data hasil penelitian telah memusat, sedangkan histogram dari data tersebut bisa dilihat pada gambar sebagai berikut: 


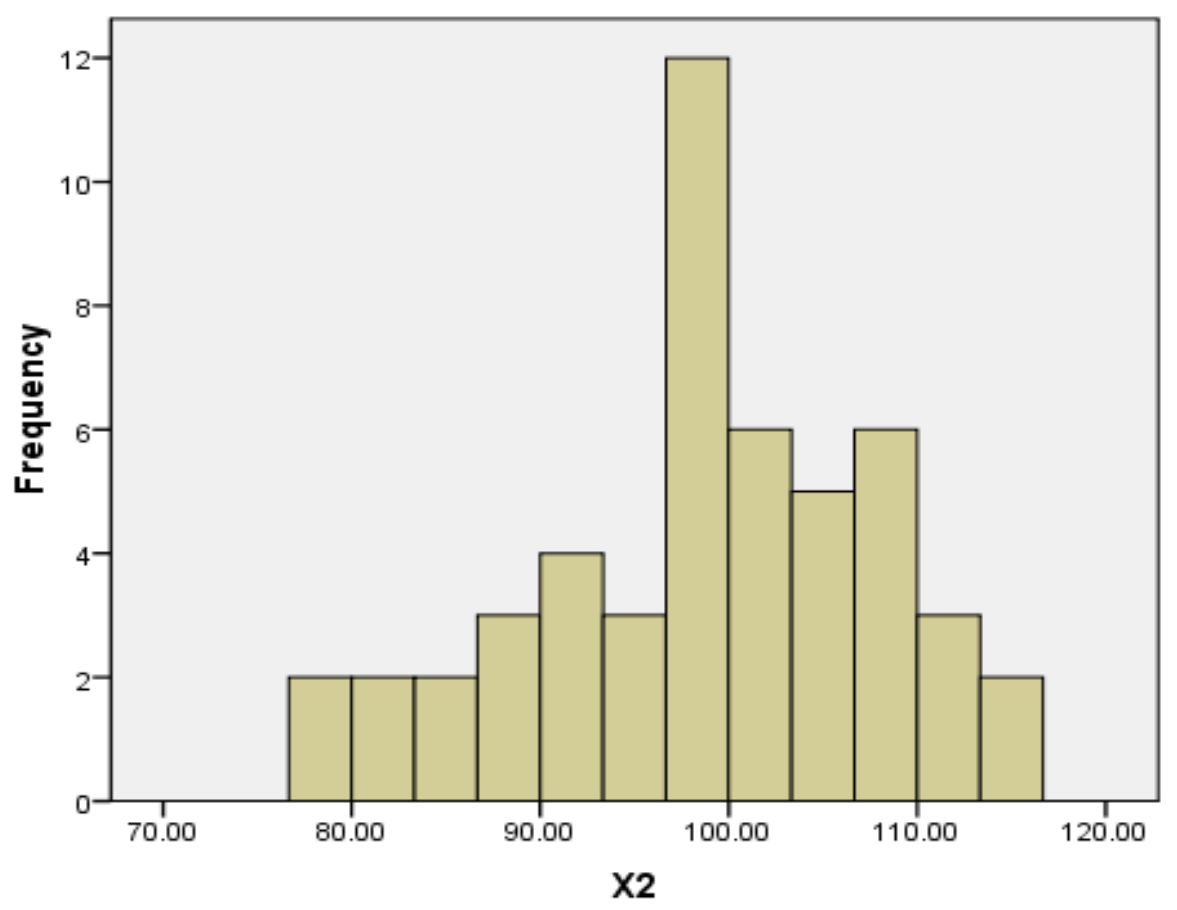

\section{Gambar 2 Histogram Data Skor Motivasi Belajar Siswa}

Pada tabel distribusi dan histrogram di atas dapat disimpulkan bahwa data skor motivasi belajar siswadalam penelitian ini memiliki sebaran yang cukup baik karena membentuk kurva cenderung normal.

\section{Analisis Data Hasil Belajar Siswa (Y)}

Skor hasil belajar siswa yang diperoleh dari para responden mempunyai rata-rata 84,16 dengan simpangan baku 5,67, median 84,50, modus 84,00, skor minimum 70 dan skor maksimum 93. Banyaknya butir pertanyaan yang valid dalam instrumen ini adalah 20 butir dengan skor minimum 0 dan maksimum 100. Skor hasil belajar siswa termasuk tinggi dengan skor simpangan baku 5,67dari rata-rata, menunjukkan perbedaan jawaban antar responden termasuk rendah. Hal ini menunjukkan bahwa data skor hasil belajar siswa dari responden tidak beragam. 
Dari deskripsi tersebut dapat dilihat bahwa antara mean dan danmedianhampir sama, yaitu 84,16dan 84,50menunjukkan bahwa data skor hasil belajar siswa yang diperoleh cukup representatif. Ha tiu dikarenakan data hasil penelitian telah memusat, sedangkan Histogram dari data tersebut bisa dilihat pada gambar berikut.

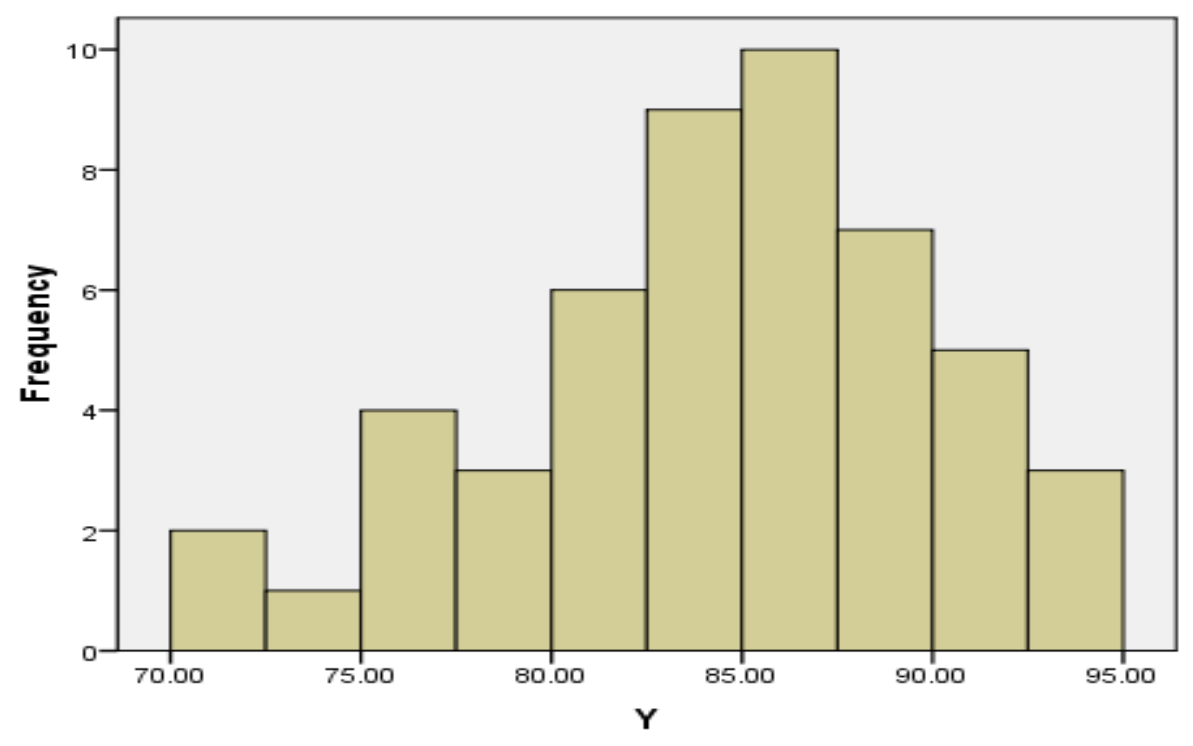

\section{Gambar 3 Histogram Data Skor Hasil Belajar Siswa}

Dari tabel distribusi dan histrogram dapat disimpulkan bahwa data skor skala hasil belajarsiswa dalam penelitian ini memiliki sebaran yang cukup baik karena membentuk kurva normal.

\section{Pengujian Persyaratan Analisis}

Pengujian persyaratan analisis data yang dilakukan dalam penelitian ini adalah pengujian normalitas, linieritas, multikolieritas dan heteroskedastisitas. Uji-uji tersebut merupakan uji persyaratan sebelum analisis regresi berganda dilakukan. 


\section{Pengujian Normalitas Data}

Pengujian normalitas data masing-masing sampel diuji melalui hipotesis berikut :

$$
\begin{aligned}
& \mathrm{H}_{0} \text { : data pada sampel tersebut berdistribusi normal } \\
& \mathrm{H}_{1} \text { : data pada sampel tersebut tidak berdistribusi normal }
\end{aligned}
$$

Perhitungan dilakukan dengan bantuan komputer melalui program aplikasi SPSS 16. Menurut ketentuan yang ada pada program tersebut maka kriteria dari normalitas data adalah "jika $p$ value (sig)> 0.05 maka $\mathrm{H}_{0}$ diterima", yang berarti data pada sampel tersebut berdistribusi normal. Nilai $p$ value (sig) adalah bilangan yang tertera pada kolom sig dalam tabel hasil/output perhitungan pengujian normalitas oleh program SPSS. Dalam hal ini digunakan metode Kolmogorov-Smirnov.Hasil perhitungan dapat dilihat pada tabel berikut.

\begin{tabular}{|c|c|c|c|c|}
\hline & & $\mathrm{X} 1$ & $\mathrm{X} 2$ & $\mathrm{Y}$ \\
\hline$n$ & & 50 & 50 & 50 \\
\hline \multirow[t]{2}{*}{ normal parameters $^{a}$} & mean & 86.3400 & 98.9800 & 84.1600 \\
\hline & std. deviation & 9.15760 & 9.23279 & 5.67256 \\
\hline \multirow[t]{3}{*}{ mostextreme differences } & absolute & .072 & .098 & .099 \\
\hline & positive & .071 & .063 & .061 \\
\hline & negative & -.072 & -.098 & -.099 \\
\hline kolmogorov-smirnov $z$ & & .507 & .691 & 700 \\
\hline
\end{tabular}

\section{Tabel 4 Rekapitulasi Hasil Pengujian Normalitas}


asymp. sig. (2-tailed)

.959

.726

.711

Pada tabel di atas terlihat bahwa nilai pada kolom Sig pada metode KolmogorovSmirnov adalah 0,507, 0,691 dan 0,700 untuk semua sampel lebih besar dari 0,05, sehingga $\mathrm{H}_{0}$ diterima, dengan kata lain bahwa data dari semua sampel pada penelitian ini berdistribusi normal.

Pengujian normalitas data masing-masing sampel juga dapat diuji melalui grafik gormal Q-Q Plot untuk setiap sampel.

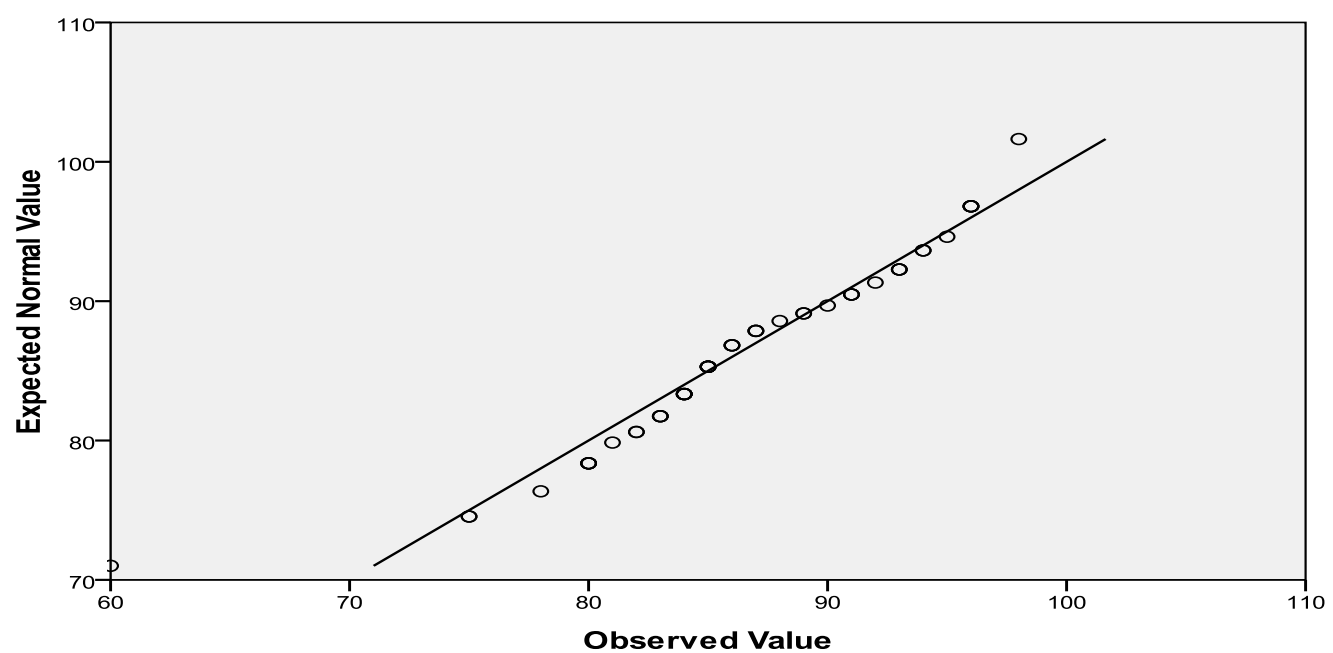

\section{Gambar 4 Diagram Normal Q-Q Plot Data Persepsi Siswa}

\section{Terhadap Kinerja Guru $\left(\mathbf{X}_{1}\right)$}

Dari gambar di atas, dapat dilihat bahwa posisi setiap data berdekatan dengan garis trend data, sehingga bisa disimpulkan bahwa data variabel persepsi siswa terhadap kinerja guru $\left(\mathrm{X}_{1}\right)$ cenderung berdistribusi normal. 
Untuk variabel motivasi belajar biswa $\left(\mathrm{X}_{2}\right)$, grafik normal Q-Q Plot terlihat pada gambar dibawah ini. Dari gambar tersebut dapat dilihat bahwa posisi setiap data berdekatan dengan garis trend data, sehingga bisa disimpulkan bahwa data variabel motivasi belajar siswa $\left(\mathrm{X}_{2}\right)$ juga cenderung berdistribusi normal.

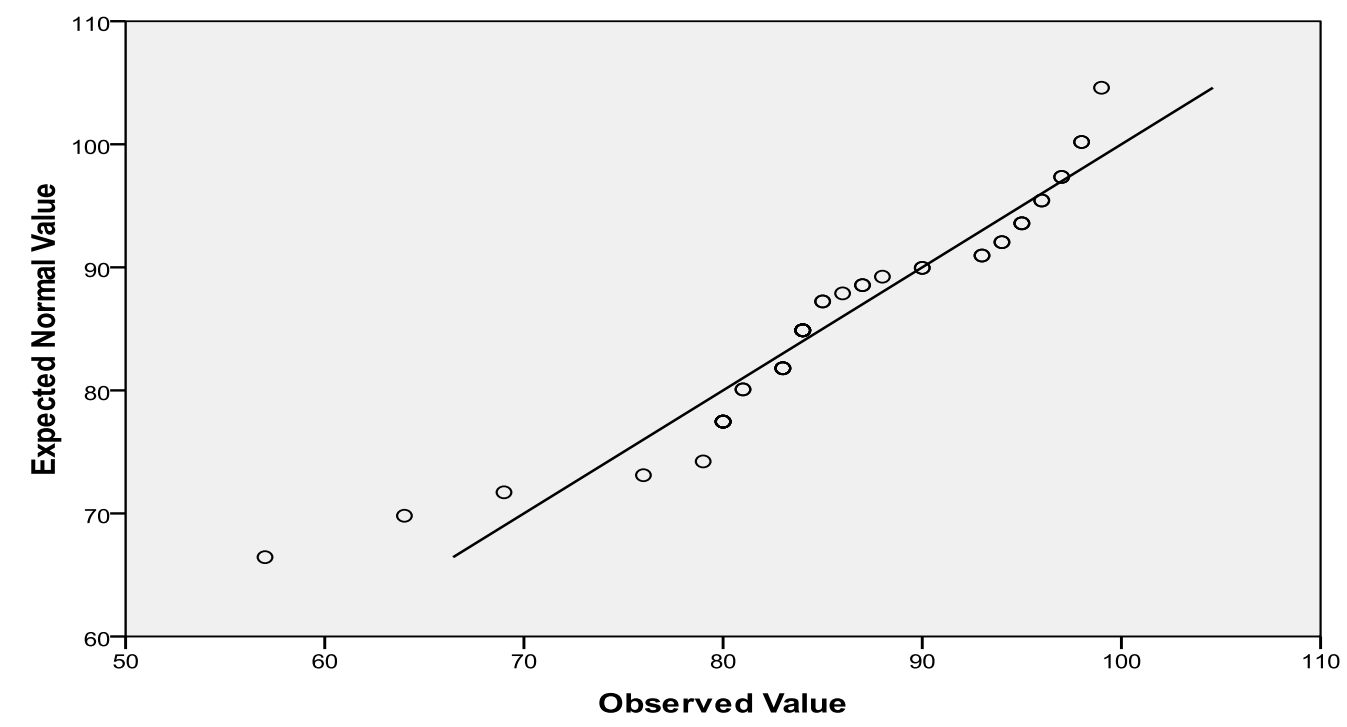

\section{Gambar 5 Histogram Normal Q-Q Plot Data Skor}

\section{Motivasi Belajar Siswa $\left(\mathbf{X}_{2}\right)$}

Dari gambar di atas, dapat dilihat bahwa posisi setiap data hasil belajarsiswa juga berdekatan dengan garis trend data, sehingga bisa disimpulkan bahwa data variabel hasil belajar siswa (Y) jugacenderung berdistribusi normal. 


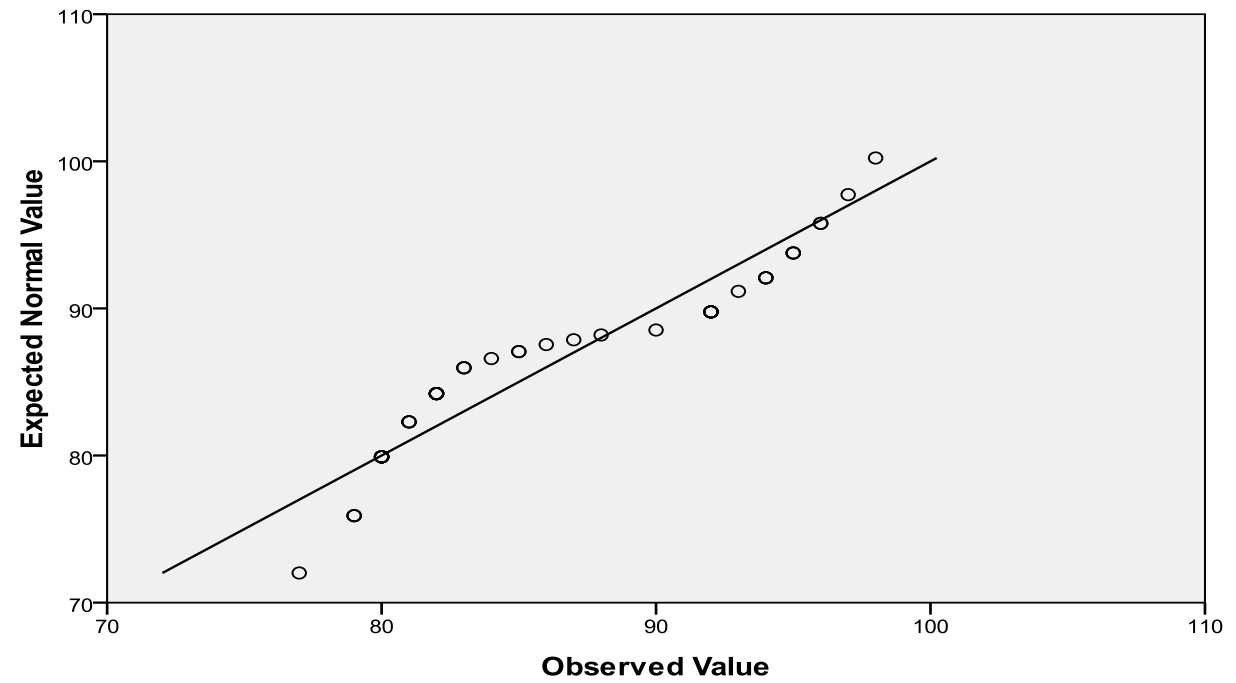

Gambar 6 Diagram Normal Q-Q Plot Data

\section{Hasil Belajar Siswa(Y)}

\section{Pengujian Linieritas Garis Regresi}

Pengujian linieritas dalam penelitian ini digunakan hipotesis berikut :

$\mathrm{H}_{0}$ : garis regresi hubungan antara varibel $\mathrm{X}$ dan variabel $\mathrm{Y}$ linier

$\mathrm{H}_{1}$ : garis regresi hubungan antara varibel $\mathrm{X}$ dan variabel $\mathrm{Y}$ tidak linier

Perhitungan dilakukan dengan bantuan komputer melalui program aplikasi SPSS 16. Menurut ketentuan yang ada pada program tersebut maka kriteria dari normalitas data adalah "jika $\mathbf{S i g}>0.05$ maka $\mathrm{H}_{0}$ diterima", yang berarti bahwa garis regresi tersebut linier. Nilai Sig adalah bilangan yang tertera pada kolom Sig baris Deviation fromLinieritydalam tabel ANOVA hasil perhitungan pengujian linieritas garis regresi oleh program SPSS. 


\section{a. Linieritas Garis Regresi Hubungan Antara Variabel $\mathrm{X}_{1}$ dengan Variabel $Y$}

Hasil perhitungan pengujian linieritas garis regresi hubungan antara variabel $\mathrm{X}_{1}$ dengan variabel Y bisa dilihat pada tabel sebagai berikut:

Tabel 5 Rekapitulasi Hasil Pengujian Linieritas Garis Regresi Hubungan Antara Variabel $X_{1}$ dengan Variabel $Y$

\section{ANOVA Table}

\begin{tabular}{|c|c|c|c|c|c|c|c|}
\hline & & & $\begin{array}{l}\text { Sum of } \\
\text { Squares }\end{array}$ & df & $\begin{array}{l}\text { Mean } \\
\text { Square }\end{array}$ & $F$ & Sig. \\
\hline $\begin{array}{l}y * \\
\mathrm{xl}\end{array}$ & within $g$ & $\begin{array}{l}\text { (combined) } \\
\text { linearity } \\
\text { deviation from } \\
\text { linearity }\end{array}$ & $\begin{array}{l}1390.387 \\
377.983 \\
1012.404 \\
186.333 \\
1576.720\end{array}$ & $\begin{array}{l}31 \\
1 \\
30\end{array}$ & $\begin{array}{l}44.851 \\
377.983 \\
33.747 \\
10.352\end{array}$ & $\begin{array}{l}4.333 \\
36.514 \\
3.260\end{array}$ & $\begin{array}{l}.001 \\
.000 \\
.055\end{array}$ \\
\hline
\end{tabular}

Pada tabel di atas terlihat bahwa nilai pada kolom Sig baris Deviation fromLinierity adalah 0,055 lebih besar dari 0,05, sehingga $\mathrm{H}_{0}$ diterima, dengan kata lain bahwa garis regresi antara varibel $\mathrm{X}_{1}$ dan variabel $\mathrm{Y}$ tersebut adalah linier. 


\section{b. Linieritas Garis Regresi Hubungan Antara Variabel $\mathbf{X}_{\mathbf{2}}$ dengan Variabel $\mathbf{Y}$}

Hasil perhitungan pengujian linieritas garis regresi hubungan antara variabel $\mathrm{X}_{2}$ dengan variabel Y bisa dilihat pada tabel berikut :

Tabel 6 Rekapitulasi Hasil Pengujian Linieritas Garis Regresi Hubungan antara Variabel $\mathbf{X}_{2}$ dengan Variabel $\mathbf{Y}$

\section{ANOVA Table}

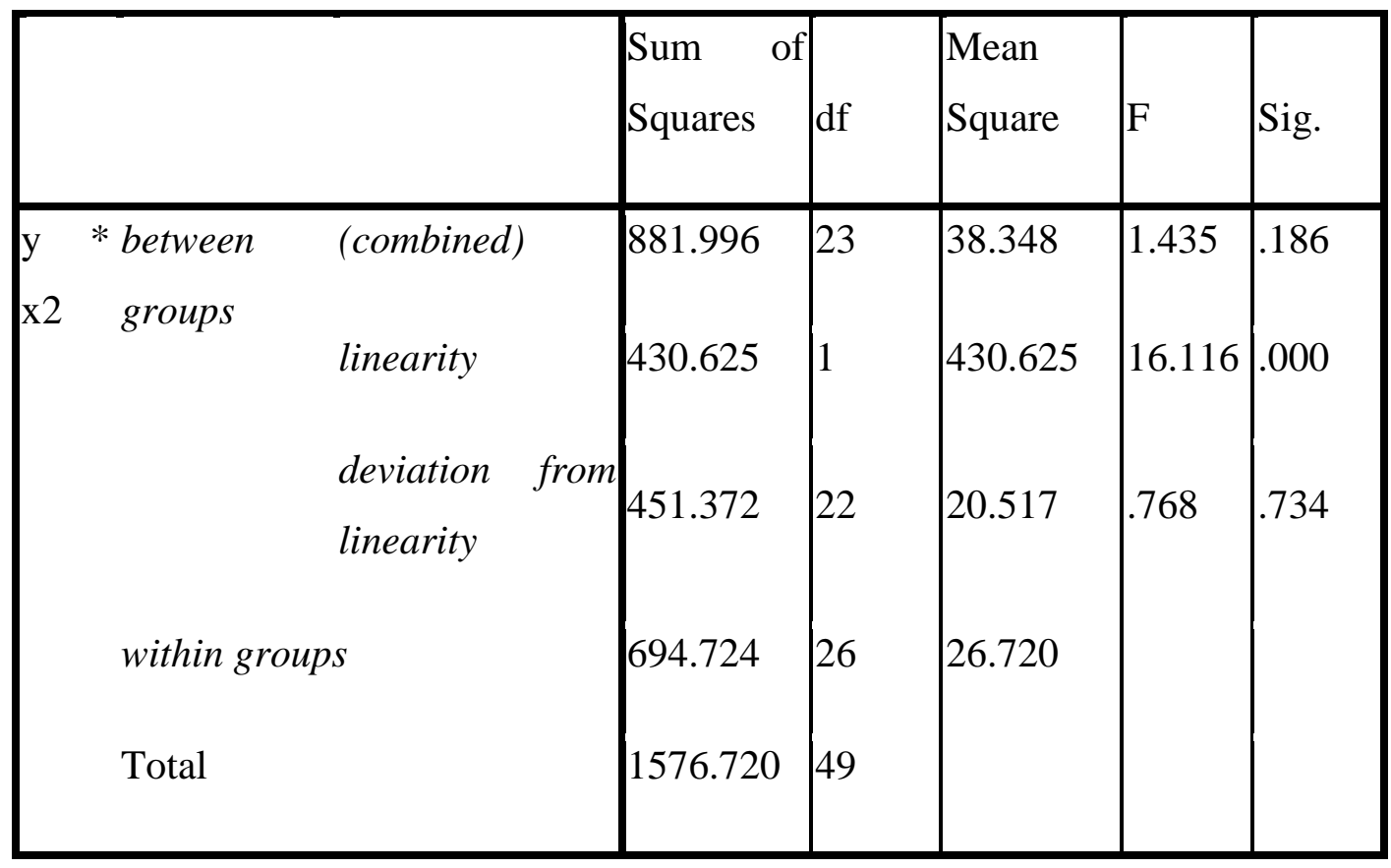

Pada tabel di atas terlihat bahwa nilai pada kolom Sig baris Deviation fromLinierity adalah 0,734 lebih besar dari 0,05 , sehingga $\mathrm{H}_{0}$ diterima, dengan kata lain bahwa garis regresi antara varibel $\mathrm{X}_{2}$ dan variabel $\mathrm{Y}$ tersebut adalah linier. Cara lain pengujian linieritas dalam penelitian ini digunakan garis regresi normal P-P plot yang terlihat pada gambar berikut: 


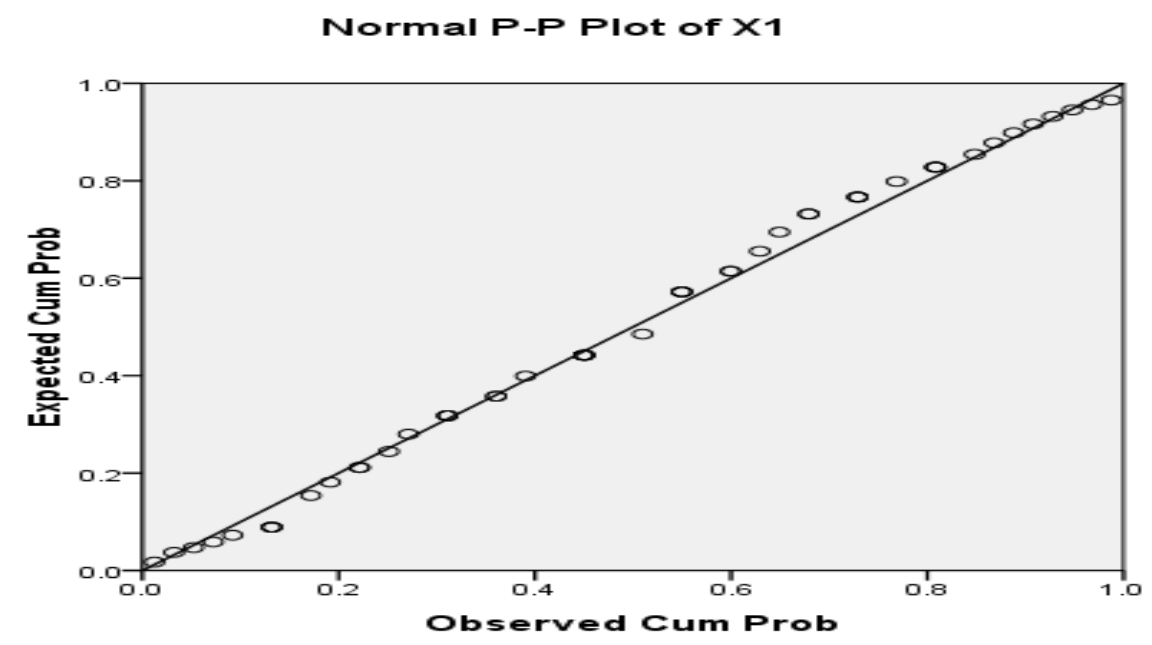

\section{Gambar 7 Diagram Normal P-PPlot $\mathrm{X}_{1}$ dengan $\mathrm{Y}$}

Berdasarkan gambar di atas, diagram P-P Plot menunjukkan garis regresi yang linier, sehingga dapat disimpulkan pasangan data antara $\mathrm{X}_{1}$ dengan $\mathrm{Y}$ secara umum dalam penelitian ini adalah linier. Begitu pula pasangan data antara $X_{2}$ dengan ya seperti terlihat pada gambar sebagai berikut: 


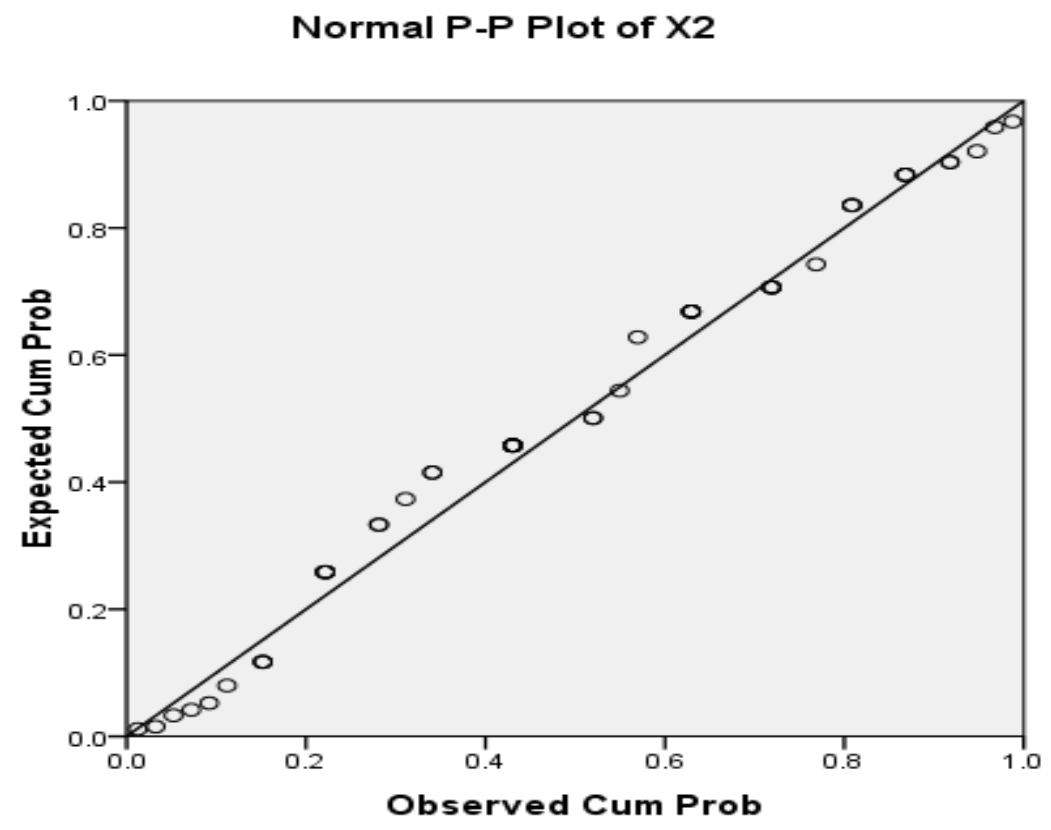

Gambar 8 Diagram Normal P-PPlot $X_{2}$ dengan $Y$

\section{PengujianMultikolinieritas}

Uji multikolinieritas bertujuan untuk menguji apakah model regresi ditemukan adanya korelasi antar variabel bebas (independent).Model regresi yang baik seharusnya tidak terjadi korelasi diantara variabel bebas.Jika variabel bebas saling berkorelasi, maka variabel-variabel ini tidak ortagonal. Variabel ortagonal adalah variabel bebas yang nilai korelasi antar sesama variabel bebas sama dengan nol. Untuk mendeteksi ada atau tidaknya multikolinieritas di dalam model regresi dapat dilihat dari nilai tolerance dan lawannya, yaitu variance inflation factor (VIF). Kedua ukuran ini menunjukkan setiap variabel bebas manakah yang dijelaskan oleh variabel bebas lainnya. Nilai cut-off yang umum dipakai adalah nilai tolerance 0,10 atau sama dengan nilai VIF diatas 10. Berikut adalah perhitungan nilai VIF pada model penelitian ini: 
Tabel 7 Uji Multikolinieritas

\section{Coefficients}

\begin{tabular}{|c|c|c|c|c|c|c|c|}
\hline \multirow[b]{2}{*}{ Model } & \multicolumn{2}{|c|}{$\begin{array}{l}\text { Unstandardized } \\
\text { Coefficients }\end{array}$} & $\begin{array}{l}\text { Stan } \\
\text { dardi } \\
\text { zed } \\
\text { Coef } \\
\text { ficie } \\
\text { nts }\end{array}$ & & & \multicolumn{2}{|c|}{$\begin{array}{l}\text { Collinearity } \\
\text { Statistics }\end{array}$} \\
\hline & B & std. error & Beta & $\mathrm{t}$ & Sig. & toleranc & VIF \\
\hline $1 \quad$ (constant) & 52.379 & 7.515 & & 6.970 & .000 & & \\
\hline $\mathrm{X} 2$ & .321 & .076 & .523 & 4.247 & .000 & 1.000 & 1.000 \\
\hline
\end{tabular}

Pada tabel di atas diperlihatkan bahwa nilai VIF pada model penelitian ini $\leq 10$, yaitu 1,000, sehingga model terbebas dari masalah multikolineritas.

\section{Pengujian Heteroskedastisitas}

Uji heteroskedastisitas adalah untuk melihat apakah terdapat ketidaksamaan varians dari residual satu ke pengamatan ke pengamatan yang lain. Model regresi yang memenuhi persyaratan adalah di mana terdapat kesamaan varians dari residual satu pengamatan ke pengamatan yang lain tetap atau disebut homoskedastisitas. Deteksi heteroskedastisitas dapat dilakukan dengan metode scatter plot dengan memplotkan nilai ZPRED (nilai prediksi) dengan ZRESID (nilai residualnya).Model yang baik didapatkan jika tidak 
terdapat pola tertentu pada grafik, seperti mengumpul di tengah, menyempit kemudian melebar atau sebaliknya melebar kemudian menyempit.Oleh karena itu berdasarkan gambar berikut.

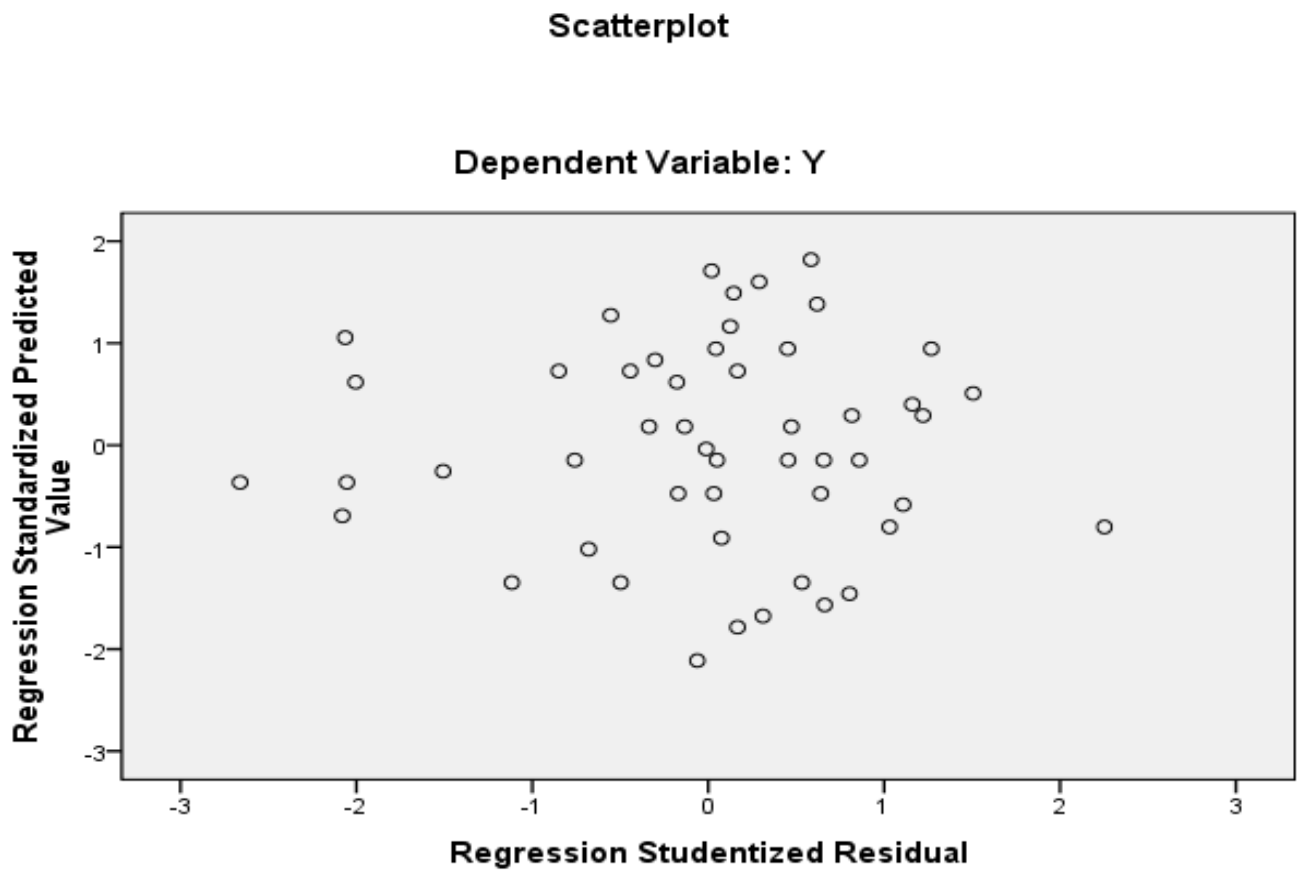

\section{Gambar 9Uji Heterokedastisitas}

Berdasarkan gambar di atas terlihat bahwa dengan memplotkan nilai ZPRED (nilai prediksi) dengan ZRESID (nilai residualnya). Model yang didapatkan tidak terdapat pola tertentu pada grafik, sehingga model terbebas dari masalah heterokedastisitas. 


\section{Pengujian Hipotesis}

Pengujian hipotesis penelitian dilakukan seperti yang telah dinyatakan pada akhir Bab III. Hasil perhitungan dan pengujian bisa dilihat pada table sebagai berikut :

Tabel 8. Hasil Perhitungan Koefisien Korelasi Pengaruh Variabel $X_{1}$ dan $X_{2}$ terhadap Variabel Y

Model Summary

\begin{tabular}{|l|l|l|l|l|}
\hline Model & $\mathrm{R}$ & R Square & $\begin{array}{l}\text { Adjusted } \\
\text { Square }\end{array}$ & $\begin{array}{l}\text { Std. Error of } \\
\text { the Estimate }\end{array}$ \\
\hline 1 & $.573^{\mathrm{a}}$ & .329 & .300 & 4.74566 \\
\hline
\end{tabular}

a. Predictors: (Constant), X2, X1

Tabel 9 Rekapitulasi Hasil Perhitungan Pengujian Signifikasi Koefisien Regresi Pengaruh Variabel $X_{2}$ dengan Variabel $Y$

ANOVA

\begin{tabular}{|l|l|l|l|l|l|}
\hline \multicolumn{2}{|l|}{$\begin{array}{l}\text { Sum } \\
\text { Squares }\end{array}$} & Df & Mean Square & $F$ & Sig. \\
\hline $1 \quad$ regression & 518.218 & 2 & 259.109 & 11.505 & $.000^{\mathrm{a}}$ \\
$\quad \begin{array}{l}\text { residual } \\
\text { Total }\end{array}$ & 1058.502 & 47 & 22.521 & & \\
\hline
\end{tabular}


ANOVA

\begin{tabular}{|c|c|c|c|c|c|}
\hline Model & $\begin{array}{ll}\text { Sum } & \text { of } \\
\text { Squares } & \end{array}$ & $D f$ & Mean Square & $F$ & Sig. \\
\hline $\begin{array}{l}\text { regression } \\
\text { residual } \\
\text { Total }\end{array}$ & $\begin{array}{l}518.218 \\
1058.502 \\
1576.720\end{array}$ & $\begin{array}{l}2 \\
47 \\
49\end{array}$ & $\begin{array}{l}259.109 \\
22.521\end{array}$ & 11.505 & $.000^{\mathrm{a}}$ \\
\hline
\end{tabular}

a. Predictors: (Constant), X2, X1

b. Dependent Variable: Y

Tabel 10 Rekapitulasi Hasil Perhitungan Persamaan Garis Regresi Pengaruh Variabel $X_{1}$ dan $X_{2}$ terhadap Variabel $Y$

\section{Coefficients $^{\mathrm{a}}$}

\begin{tabular}{|c|c|c|c|c|c|c|c|}
\hline \multirow[b]{2}{*}{ Model } & \multicolumn{2}{|c|}{$\begin{array}{l}\text { Unstandardized } \\
\text { Coefficients }\end{array}$} & \multirow{2}{*}{\begin{tabular}{|l} 
Standardize \\
$d$ \\
Coefficients
\end{tabular}} & \multirow[b]{2}{*}{$t$} & \multirow[b]{2}{*}{ Sig. } & \multicolumn{2}{|c|}{$\begin{array}{l}\text { Collinearity } \\
\text { Statistics }\end{array}$} \\
\hline & $B$ & $\begin{array}{l}\text { Std. } \\
\text { Error }\end{array}$ & & & & $\begin{array}{l}\text { Toleran } \\
\text { ce }\end{array}$ & VIF \\
\hline$($ constant $)$ & 46.912 & 7.808 & & 6.008 & .000 & & \\
\hline
\end{tabular}




\begin{tabular}{|l|l|l|l|l|l|l|l|}
$\mathrm{X} 1$ & .177 & .090 & .286 & 2.172 & .043 & .681 & 1.468 \\
$\mathrm{X} 2$ & .222 & .089 & .361 & 2.495 & .016 & .681 & 1.468 \\
\hline
\end{tabular}

\section{Pengaruh Persepsi Siswa terhadap Kinerja Guru $\left(X_{1}\right)$ dan Motivasi Belajar Siswa $\left(\mathrm{X}_{2}\right)$ secara Bersama-sama terhadap Hasil Belajar Siswa(Y)}

Hipotesis pengaruh ini sebagai berikut. $H_{0}: \beta_{1}=\beta_{2}=0$

$$
\mathrm{H}_{1}: \beta_{1} \neq 0 \text { atau } \beta_{2} \neq 0 \quad ;
$$

Artinya :

$\mathrm{H}_{0}$ : tidak terdapat pengaruh yang signifikan Persepsi Siswa Terhadap Kinerja Guru $\left(\mathrm{X}_{1}\right)$ dan Motivasi Belajar Siswa $\left(\mathrm{X}_{2}\right)$ secara bersama-sama terhadap Hasil Belajar Siswa (Y).

$\mathrm{H}_{1}$ : terdapat pengaruh yang signifikan Persepsi Siswa Terhadap Kinerja Guru $\left(\mathrm{X}_{1}\right)$ dan Motivasi Belajar Siswa $\left(\mathrm{X}_{2}\right)$ secara bersama-sama terhadap Hasil Belajar Siswa(Y).

Dari tabel 4.6.terlihat bahwa koefisien korelasi ganda pengaruh variabel bebas Persepsi Siswa Terhadap Kinerja Guru $\left(\mathrm{X}_{1}\right)$ dan Motivasi Belajar Siswa $\left(\mathrm{X}_{2}\right)$ secara bersama-sama terhadap Hasil Belajar Siswa(Y) adalah sebesar 0,573. Dari perhitungan tersebut di peroleh bahwa koefisien korelasi tersebut menjelaskan bahwa hubungan Persepsi Siswa Terhadap Kinerja Guru $\left(\mathrm{X}_{1}\right)$ dan Motivasi Belajar Siswa $\left(\mathrm{X}_{2}\right)$ secara bersama-sama terhadap Hasil Belajar Siswa(Y) adalah kuat dan positif.Dengan kata lain, terdapat pengaruh yang signifikan variabel bebas Persepsi Siswa Terhadap Kinerja Guru 
$\left(\mathrm{X}_{1}\right)$ dan Motivasi Belajar Siswa $\left(\mathrm{X}_{2}\right)$ secara bersama-sama terhadap Hasil Belajar $\operatorname{Siswa}(\mathrm{Y})$.

Dengan demikian, koefisien determinasinya sebesar 0,329 menunjukkan bahwa besarnya kontribusi Persepsi Siswa Terhadap Kinerja Guru dan Motivasi Belajar Siswasecara bersama-sama terhadap Hasil Belajar Siswaadalah sebesar 32,9\%, sisanya $(60,1 \%)$ disebabkan oleh faktor lain yang tidak diteliti dalam penelitian ini.

Pengujian hipotesis melalui analisis regresi dberganda peroleh hasil perhitungan terlihat pada tabel 4.6, tabel 4.7 dan tabel 4.8. diperoleh persamaan garis regresi yang merepresentasikan pengaruh variabel $\mathrm{X}_{1}$ dan $\mathrm{X}_{2}$ terhadap variabel $\mathrm{Y}$, yaitu : $\widehat{\mathrm{Y}}=46.91+$ $0,177 \mathrm{X}_{1}+0,222 \mathrm{X}_{2}+\mathrm{e}$

Pengujian signifikansi garis regresi regresi tersebut adalah dengan memperhatikan hasil perhitungan yang ada pada tabel 4.7. Menurut ketentuan yang ada, kriteria signifikansi regresi tersebut adalah "jika $\mathrm{Sig}<0.05$ maka $\mathrm{H}_{0}$ ditolak" atau "jika $\mathrm{F}_{\text {hitung }}>$ $\mathrm{F}_{\text {tabel }}$ maka $\mathrm{H}_{0}$ ditolak", yang berarti bahwa koefisien regresi tersebut signifikan, dengan kata lain terdapat pengaruh yang signifikan variabel bebas $\mathrm{X}_{1}$ dan $\mathrm{X}_{2}$ terhadap variabel terikat Y. Nilai Sig adalah bilangan yang tertera pada kolom Sig dalam tabel 4.7. Nilai $F_{\text {hitung }}$ adalah bilangan yang tertera pada kolom $F$ dalam tabel 4.7. Sedangkan nilai $F_{\text {tabel }}$ adalah nilai tabel distribusi $\mathrm{F}$ untuk taraf nyata $5 \%$ dengan derajat pembilang $(\mathrm{k})=2$ dan derajat penyebut $(\mathrm{n}-\mathrm{k}-1)=47$ yakni $\mathrm{n}$ adalah banyaknya responden, dan $\mathrm{k}$ adalah banyaknya variabel bebas.

Dari Tabel 4.7. terlihat bahwa nilai Sig $=0.000$ dan $F_{\text {hitung }}=11,505$, sedangkan $F_{\text {tabel }}=3,15$. Karena nilai $\operatorname{Sig}<0,05$ dan $F_{\text {hitung }}>F_{\text {tabel }}$ maka $H_{0}$ di tolak yang berarti bahwa koefisien regresi tersebut signifikan. Dengan kata lain, terdapat pengaruh yang signifikan variabel bebas Persepsi Siswa Terhadap Kinerja Guru $\left(\mathrm{X}_{1}\right)$ dan Motivasi Belajar $\operatorname{Siswa}\left(\mathrm{X}_{2}\right)$ secara bersama-sama terhadap Hasil Belajar Siswa(Y). 
Hasil pengujian korelasi dan regresi tersebutdapat disimpulkan bahwa terdapat pengaruh yang signifikan variabel bebas Persepsi Siswa Terhadap Kinerja Guru $\left(\mathrm{X}_{1}\right)$ dan Motivasi Belajar Siswa $\left(\mathrm{X}_{2}\right)$ secara bersama-sama terhadap Hasil Belajar Siswa(Y).

\section{Pengaruh Persepsi Siswa Terhadap Kinerja Guru $\left(X_{1}\right)$ terhadap Hasil Belajar Siswa $(\mathbf{Y})$}

Hipotesis pengaruh ini adalah :

$$
\begin{aligned}
& \mathrm{H}_{0}: \beta_{\mathrm{y} 1}=0 \\
& \mathrm{H}_{1}: \beta_{\mathrm{y} 1} \neq 0
\end{aligned}
$$

Artinya :

$\mathrm{H}_{0}$ : Tidak terdapat pengaruh yang signifikan Persepsi Siswa Terhadap Kinerja Guru terhadap Hasil Belajar Siswa.

$\mathrm{H}_{1}$ : Terdapat pengaruh yang signifikan Persepsi Siswa Terhadap Kinerja Guru terhadap Hasil Belajar Siswa

Untuk membuktikan hipotesis tersebut adalah dengan memperhatikan nilai yang tertera pada kolom t atau kolom Sig untuk baris Persepsi Siswa Terhadap Kinerja Guru $\left(\mathrm{X}_{1}\right)$ pada Tabel 4.8. Menurut ketentuan yang ada, kriteria signifikansi regresi tersebut adalah "jika $t_{\text {hitung }}>\mathrm{t}_{\text {tabel }}$ maka $\mathrm{H}_{0}$ ditolak" atau "jika $\mathrm{Sig}<0,05$ maka $\mathrm{H}_{0}$ ditolak", yang berarti bahwa terdapat pengaruh yang signifikan variabel bebas $\mathrm{X}_{1}$ terhadap variabel terikat $\mathrm{Y}$. Nilai Sig adalah bilangan yang tertera pada kolom Sig untuk baris Persepsi Siswa Terhadap Kinerja Guru $\left(\mathrm{X}_{1}\right)$ dalam Tabel 4.8. Nilai $\mathrm{t}_{\text {hitung }}$ adalah bilangan yang tertera pada kolom $\mathrm{t}$ untuk baris Persepsi Siswa terhadap Kinerja Guru $\left(\mathrm{X}_{1}\right)$ dalam Tabel 4.8. Dengan demikian, nilai $\mathrm{t}_{\text {tabel }}$ adalah nilai tabel distribusi $\mathrm{t}$ untuk taraf nyata 5\% dengan derajat kepercayaan ( $\mathrm{df}$ $=\mathrm{n}-2)=48$ dimana $\mathrm{n}$ adalah banyaknya responden. 
Dari Tabel 4.8. terlihat bahwa nilai Sig $=0.000$ dan $\mathbf{t}_{\text {hitung }}=2,172$, sedangkan $\mathbf{t}_{\text {tabel }}$ $=2,01$. Karena nilai Sig $<0,05$ dan $\mathbf{t}_{\text {hitung }}>\mathbf{t}_{\text {tabel }}$ maka $\mathrm{H}_{0}$ di tolak yang berarti terdapat pengaruh yang signifikan variabel bebas Persepsi Siswa Terhadap Kinerja Guru terhadap variabel terikat Hasil Belajar Siswa.

Dari hasil pengujian korelasi, pengujian regresi maupun dengan melihat model garis tersebut maka bisa disimpulkan bahwa terdapat pengaruh yang signifikan variabel bebas $\mathrm{X}_{1}$ (Persepsi Siswa Terhadap Kinerja Guru) terhadap variabel terikat Y (Hasil Belajar Siswa).

\section{Pengaruh Motivasi Belajar Siswa $\left(\mathbf{X}_{2}\right)$ terhadap Hasil Belajar Siswa(Y)}

Hipotesis pengaruh ini adalah sebagai berikut.

$$
\begin{aligned}
& \mathrm{H}_{0}: \beta_{2}=0 \\
& \mathrm{H}_{1}: \beta_{2} \neq 0 ;
\end{aligned}
$$

Artinya:

$\mathrm{H}_{0}$ : Tidak terdapat pengaruh yang signifikan Motivasi Belajar Siswaterhadap Hasil Belajar Siswa

$\mathrm{H}_{1}$ : Terdapat pengaruh yang signifikan Motivasi Belajar Siswaterhadap Hasil Belajar Siswa

Untuk membuktikan hipotesis tersebut adalah dengan memperhatikan nilai yang tertera pada kolom t atau kolom Sig untuk baris Motivasi Belajar Siswa(Variabel $\mathrm{X}_{2}$ ) pada Tabel 4.8. Menurut ketentuan yang ada, kriteria signifikansi regresi tersebut adalah "jika $t_{\text {hitung }}>t_{\text {tabel }}$ maka $\mathrm{H}_{0}$ ditolak" atau "jika Sig $<0,05$ maka $\mathrm{H}_{0}$ ditolak", yang berarti bahwa terdapat pengaruh yang signifikan variabel bebas $\mathrm{X}_{2}$ terhadap variabel terikat $\mathrm{Y}$. Nilai Sig adalah bilangan yang tertera pada kolom Sig untuk baris Motivasi Belajar Siswa(Variabel 
$\mathrm{X}_{2}$ ) dalam Tabel 4.8. Nilai $\mathrm{t}_{\text {hitung }}$ adalah bilangan yang tertera pada kolom $\mathrm{t}$ untuk baris Motivasi Belajar Siswa(Variabel $\mathrm{X}_{2}$ ) dalam Tabel 4.8. Sedangkan nilai $\mathrm{t}_{\text {tabel }}$ adalah nilai tabel distribusi t untuk taraf nyata 5\% dengan derajat kepercayaan $(\mathrm{df}=\mathrm{n}-2)=48$ yakni $\mathrm{n}$ adalah banyaknya responden.

Dari Tabel 4.8. terlihat bahwa nilai Sig $=0.000$ dan $\mathbf{t}_{\text {hitung }}=2.495$, sedangkan $\mathbf{t}_{\text {tabel }}$ $=2,01$. Karena nilai Sig $<0,05$ dan $\mathbf{t}_{\text {hitung }}>\mathbf{t}_{\text {tabel }}$ maka $\mathrm{H}_{0}$ di tolak yang berarti terdapat pengaruh yang signifikan variabel bebas $\mathrm{X}_{2}$ (Motivasi Belajar Siswa) terhadap variabel terikat Y (Hasil Belajar Siswa).

Hasil pengujian korelasi, pengujian regresi, dan dengan melihat model garis tersebut, dapat disimpulkan bahSwa terdapat pengaruh yang signifikan variabel bebas $\mathrm{X}_{2}$ (Motivasi Belajar Siswa) terhadap variabel terikat Y (Hasil Belajar Siswa).

\section{Pembahasan/Interpretasi Hasil Penelitian}

\section{Pengaruh Persepsi Siswa terhadap Kinerja Guru dan Motivasi Belajar Siswasecara Bersama-sama terhadap Hasil Belajar Siswa.}

Dari deskripsi data setelah dilakukan analisis korelasi diperoleh koefisien korelasi sebesar 0,573dan koefisien determinasi sebesar 32,9\%, setelah dilakukan pengujian dengan program SPSS terbukti bahwa koefisien korelasi tersebut signifikan. Hal ini berarti bahwa terdapat pengaruh variabel bebas $X_{1}$ (Persepsi Siswa Terhadap Kinerja Guru) dan $X_{2}$ (Motivasi Belajar Siswa) secara bersama-sama terhadap variabel terikat Y (Hasil Belajar Siswa).

Analisis regresi diperoleh persamaan garis regresi $\widehat{\mathbf{Y}}=46.912+0,177 \mathrm{X}_{1}+0,222 \mathrm{X}_{2}$ + e.. Nilai konstanta $=46.912$ menunjukkan bahwa dengan Persepsi Siswa Terhadap 
Kinerja Guru dan Motivasi Belajar Siswa paling rendah, siswa sebagai unit analisis dalam penelitian ini dapat mencapai hasil belajar yang cukup baik, yakni sebesar 46,912 persen, sedangkan nilai koefisien regresi sebesar 0,177 dan 0,222 menunjukkan bahwa terdapat pengaruh positif variabel bebas $\mathrm{X}_{1}$ (Persepsi Siswa Terhadap Kinerja Guru) dan $\mathrm{X}_{2}$ (Motivasi Belajar Siswa)secara bersama-sama terhadap variabel terikat Y (Hasil Belajar Siswa). Selain itu, makna lain adalah setiap ada kenaikan satu satuan Persepsi Siswa Terhadap Kinerja Guru maka akan terdapat kenaikan Hasil Belajar Siswasebesar 0,177satuan, dan setiap ada kenaikan satu satuan Motivasi Belajar Siswa, maka akan terdapat kenaikan Hasil Belajar Siswasebesar 0,222 satuan.

Menurut sintesis teori yang ada, hasil belajar siswamerupakan hasil yang dicapai oleh siswa dalam proses belajar yang diikutinya dalam kegiatan PBM di kelas yang terindikasi pada kemampuan kognitif, afektif, dan psikomotorik. Hasil belajar siswa merupakan dampak dari proses yang dilakukan dan didalamnya terdapat berbagai faktor yang memengaruhinya. Faktu yang memegaruhi itu diantaranya kinerja guru dalam mengajar berupa perilaku guru dalam merencanakan pembelajaran, kegiatan melaksanakan pembelajaran secara interaktif, dan menyenangkan. Selain itu, mengevaluasi sesuai dengan tata cara yang benar dan faktor internal siswa dalam mengikuti kegiatan pembelajaran.

Menurut Undang-undang No 14 Tahun 2005 Hasil Belajar Siswa adalah hasil kerja atau prestasi kerja yang dicapai oleh seorang guru berdasarkan kemampuannya. Oleh karena itu, guru wajib memiliki kualifikasi akademik, kompetensi, sertifikat pendidik, sehat jasmani dan rohani, dan memenuhi kualifikasi lain yang dipersyaratkan satuan pendidikan tempat bertugas. Hasil Belajar Siswa adalah suatu hasil atau taraf kesuksesan yang dicapai oleh seorang guru dalam memberikan ilmu kepada siswa, berdasarkan kriteria tertentu dan di evaluasi oleh orang-orang tertentu.

Persepsi siswa terhadap hasil belajar siswa dapat diartikan responsdan pandangan siswa sebagai peserta didik dalam menilai dan merespon perilaku guru dalam 
melaksanakan tugas dan kewajibannya sebagai pendidik dalam pembelajaran yang di dalamnya melibatkan pengetahuan, keterampilan dan kemauan dalam mengajar. Kinerja guru dalam penelitian ini tidak terlepas dari kompetensi yang dimilikinya sesuai dengan tuntutan Undang-Undang khususnya adalah Undang-Undang Nomor 14 tahun 2005 tentang guru dan dosen yang di dalamnya mensyaratkan guru adanya penguasaan kopetensi yakni kompetensi kepribadian, kompetensi social, kompetensi pedagogik, dan kompetensi professional.

Kinerja guru tidak akan berjalan dengan efektif dan efisien tanpa adanya penguasaan kompetensi di atas dalam menjalankan tugasnya karena tanpa skill yang dimiliki, maka tujuan pembelajaran sulit akan dapat dicapai dengan optimal. Dengan demikian, kinerja guru merupakan variabel yang dapat berperan mendorong ketercapaian hasil pembelajaran siswa.

Motivasi belajar siswa adalah dorongan yang kuat dalam diri siswa untuk mengikuti kegiatan pembelajaran. Indikasi bahwa seorang siswa memiliki dorongan motivasi yang kuat adalah adanya keinginan yang kuat untuk belajar.Seorang siswa dalam mengikuti proses belajar mengajar di kelas hendaknya mempuyai kemauan yang keras. Selain itu, seorang soswa hendaknya menaati berbagai aturan yang diberlakukan di sekolah, serta tidak mudah putus asa dalam meghadapi berbagai kesulitan dan tantangan dalam belajar.

Tinggi rendahnya motivasi belajar siswa sangat bergantung pada persepsi diri terhadap makna belajar yang diikuti dan dorongan unsur eksternal yang turut membuat siswa memiliki motivasi. Oleh karena itu, diperlukan unsur kesternal seperti guru, lingkungan, metode pembelajaran, peran orang tua, dan kondisi belajar yang harus diciptakan guna mendorong siswa memiliki motivasi yang kuat.

Dari hasil penelitian ditemukan bahwa motivasi belajar siswa memiliki pengaruh terhadap hasil belajar yang dicapainya. Artinya semakin tinggi motivasi dalam belajar, 
semakin tinggi pula hasil belajar yang dicapainya.Akan tetapi, semakin rendah motivasi dalam belajar, maka akan semakin rendah pula hasil belajarnya. Dengan demikian, jika kita hendak meningkatkan hasil belajar siswa, terlebih dahulu harus ditingkatkan motivasi belajarnya.

Dari hasil perhitungan data secara kuantitatif diperoleh skor yang menyatakan bahwa kedua variabel di atas memiliki pengaruh terhadap hasil belajar yang dicapai siswa. Haal itu membukytikan bahwa pengaruh yang lebih kuat adalah pengaruh motivasi belajar terhadap hasil belajar, begitu pula secara teoretik bahwa variabel dimaksud juga memiliki kaitan erat dengan hasil belajar siswa. Berdasarkan uraian tersebut, penulis menyimpulkna bahwa persepsi siswa terhadapkinerja guru dan motivasi belajar siswa mempunyai pengaruh yang positif dan signifikan terhadap hasil belajar siswa.

\section{Pengaruh Persepsi Siswa Terhadap Kinerja Guru terhadap Hasil Belajar Siswa.}

Dari pengujian hipotesis diperoleh bahwanilai Sig $=0.043$ dan $t_{\text {hitung }}=2,172$, $\mathbf{t}_{\text {tabel }}=2,01$. Karena nilai Sig $<0,05$ dan $\mathbf{t}_{\text {hitung }}>\mathbf{t}_{\text {tabel }}$ maka $\mathrm{H}_{0}$ ditolak yang berarti terdapat pengaruh yang signifikan variabel bebas persepsi siswa terhadap kinerja guru terhadap variabel terikat hasil belajar siswa. Menurut sintesis teori bahwa persepsi siswa terhadap kinerja guru adalah penilaian dan respons siswa terhadap perilaku guru dalam menjalankan pekerjaannya sebagai seorang pendidik yang di dalamnya terdapat unsur kemauan, keterampilan, dan pengetahuan yang dimilikinya. Kemauan berarti adanya keinginan guru dalam menjalankan tugas secara benar dan efektif sesuai dengan tugas pokok dan fungsinya sebagai seorang pendidik.Keterampilan berarti kepemilikan guru atas berbagai keahlian dalam mengajar seperti keahlian dalam membuka dan menutup pelajaran, keahlian dalam menjelaskan materi pelajaran, keahlian dalam membuat pertanyaan, keahlian dalam menjawab pertanyaan, mengelola kelas, membuat variasi pembelajaran, dan membimbing 
siswa. Unsur pengetahuan guru seberapa jauh. Untuk itu, seorang guru hendaknya memiliki informasi dan pengetahuan tentang materi yang diajarkannya.

Berdasarkan temuan penelitian, guru yang memiliki kinerja baik dalam melaksanakan tugasnya berpengaruh terhadap hasil belajar yang dicapai siswa didiknya, artinya semakin baik kinerja guru maka akan semakin baik pula hasil belajar yang dicapai siswa.

Dari hasil analisis kuantitatif dan sintesis teori tentang variabel di atas, diperoleh kesimpulan bahwa persepsi siswa terhadap kinerja guru mempunyai pengaruh yang positif dan signifikan terhadap hasil belajar siswa. Dengan demikian, hipotesis penelitian yang menyatakan adanya pengaruh antarvariabel di atas diterima.

\section{Pengaruh Motivasi Belajar Siswa $\left(X_{2}\right)$ terhadap Hasil Belajar Siswa(Y)}

Dari pengujian hipotesis diperoleh bahwa nilai Sig $=0.000$ dan $\mathbf{t}_{\text {hitung }}=2.495$, sedangkan $\mathbf{t}_{\text {tabel }}=2,01$. Karena nilai $\operatorname{Sig}<0,05$ dan $\mathbf{t}_{\text {hitung }}>\mathbf{t}_{\text {tabel }}$ maka $\mathrm{H}_{0}$ di tolak yang berarti terdapat pengaruh yang signifikan variabel bebas $\mathrm{X}_{2}$ (Motivasi Belajar Siswa) terhadap variabel terikat Y (Hasil Belajar Siswa).

Menurut sintesis teori, motivasi belajar siswa merupakan dorongan yang ada dalam diri setiap individu siswa untuk mengikuti kegiatan belajar mengajar di sekolah. Selain itu, seorang siswaada keinginan yang tinggi dan dapat mencapai prestasi yang lebih baik dan mempunyai emangat yang kuat, sehingga tidak mudah putus asa dalam menghadapi berbagai hal terkait dengan tentangan dalam belajar.

Motivasi belajar siswa dapat ditingkatkan, jika siswa yang bersangkutan memiliki persepsi positif terhadap makna belajar dan pentingnya belajar untuk peningkatan kualitas dirinya. Selain itu, seorang siswa mampu memanipulasi kondisi sehingga dapat menarik motivasi belajar siswa seperti peran guru, orang tua, dan masyarakat . 
Berdasarkan temuan penelitian, siswa yang memiliki motivasi tinggi dalam belajar memiliki pengaruh kuat terhadap peningkatan hasil belajar siswa. Kekuatan pengaruh motivasi belajar ini mengalahkan pengaruh faktor luar berupa kinerja guru. Hal ini terbukti baik secara perhitungan kuantitatif maupun sintesis teori yang menyatakan adanya keterkaitan antara motivasi belajar dengan pencapaian hasil belajar.

\section{SIMPULAN}

Penelitian mengenai pengaruh pengaruh persepsi siswa terhadap kinerja guru dan motivasi belajar terhadap hasil belajar menulis bahasa Indonesia siswa SMA Swasta di Jakarta Timur dapat dsimpulkan seperti berikut.

1. Terdapat pengaruh yang positif dan signifikan persepsi siswa terhadap kinerja guru $\left(\mathrm{X}_{1}\right)$ dan motivasi belajar $\left(\mathrm{X}_{2}\right)$ terhadap hasil belajar menulis bahasa Indonesia siswa $(\mathrm{Y})$.

Hal ini terlihat dari nilai Sig $=0.000$ dan $F_{\text {hitung }}=11,505$, sedangkan $F_{\text {tabel }}=3,15$. Karena nilai $\operatorname{Sig}<0,05$ dan $F_{\text {hitung }}>F_{\text {tabel }}$ maka $\mathrm{H}_{0}$ di tolak yang berarti bahwa koefisien regresi tersebut signifikan. Dengan kata lain,terdapat pengaruh yang signifikan variabel bebas persepsi siswa terhadap kinerja guru $\left(\mathrm{X}_{1}\right)$ dan motivasi belajar $\left(\mathrm{X}_{2}\right)$ secara bersama-sama terhadap hasil belajar siswa (Y).

2. Terdapat pengaruh yang positif dan signifikan persepsi siswa terhadap kinerja guru $\left(\mathrm{X}_{1}\right)$ terhadap hasil belajar siswa (Y).Hal ini terlihat dari nilai $\mathbf{S i g}=0.000$ dan $\mathbf{t}_{\text {hitung }}=2,172$, sedangkan $\mathbf{t}_{\text {tabel }}=2,01$. Karena nilai Sig $<0,05$ dan $\mathbf{t}_{\text {hitung }}>\mathbf{t}_{\text {tabel }}$ maka $\mathrm{H}_{0}$ ditolak yang berarti terdapat pengaruh yang signifikan variabel bebas persepsi siswa terhadap kinerja guru terhadap variabel terikat hasil belajar siswa.

3. Terdapat pengaruh yang positif dan signifikan motivasi belajar siswa $\left(\mathrm{X}_{2}\right)$ terhadap hasil belajar siswa (Y). Dengan demikian, pengujian hipotesis diperoleh bahwa nilai Sig = 0.016 dan $\mathbf{t}_{\text {hitung }}=2,495$, sedangkan $\mathbf{t}_{\text {tabel }}=2,01$. Karena nilai Sig $<0,05$ dan $\mathbf{t}_{\text {hitung }}>\mathbf{t}_{\text {tabel }}$ 
maka $\mathrm{H}_{0}$ ditolak yang berarti terdapat pengaruh yang signifikan variabel bebas $\mathrm{X}_{2}$ (motivasi belajar) terhadap variabel terikat $\mathrm{Y}$ (hasil belajar siswa) 


\section{DAFTAR PUSTAKA}

Anwar, Saifuddin. 2001. PedomanPendidikandanPengajaran. Surabaya: Usaha Nasional.

Buss, Arnol.2001. Psychologi Behavior in Perspective. New York: John Wiley and Sons, Inc.

Colquitt, Jasson A, Jeffery A. Lapine, \& Michael J. Wesson. 2009. Organizational Behavior: Improving Performance and Commitment in the Workplace. New Examplary Programs. USA: Jossey-Bass.

Depdiknas.2002. PengembanganKurikulumdanSistemPengujianBerbasisKompetensi, Surabaya: Depdikbud.

Depdiknas. 2006. Warta Hukum dan Perundang-undangan.Jakarta: Dirjen Dikdasmen.

Dewi SP dan Siregar Eveline. 2004. Mozaik Teknologi Pendidikan. Jakarta: UNJ.

Dick Walter and Carey Lou. 2001. The Sistematyc Design of Instruction. New York :Harper Collins College Publishers.

Dimyati dan Mulyono. 2002. Belajar dan Pembelajaran.Bandung: Rineka Cipta.

Djaali. 2000. Pengukuran dalam Bidang Pendidikan. Jakarta: PPS UNJ.

Hamalik, Oemar. 2001. Metode Belajar dan Kesulitan Belajar. Bandung: Tarsito.

John P. Wilson. 1999. Human Resources Management: Learning and Training for Individuals and Organizations. London: Kogan Page Limited.

Lang, Helmut R \& David N. Evans. 2006. Models, Strategies, and Methods. NewYork: McGraw-Hill-Irwin.

Lunenburg, Fred C \& Beverly J. Irby. 2006. The Principalship. Vision to Action.USA:

Nasution,S. 2000. DidaktikAzaz-azazMengajar. Bandung: Jemmar. 
Nurhadi dkk.1999. PengajaranKonstektualdanPenerapnnya dalamPendidikan. Surabaya: Usaha Nasional.

Orlich, Donald C. et al. 2010. Teaching Strategies a Guide to Effective Instruction. USA: Wadsworth.

Rakhmat, Jalaludin. 2000. Psikologi Komunikasi.Bandung: PT Remaja Rosdakarya.

Schunk, Dale H:;Paul R. Pintrich; Judith L. Meece. 2008. Motivation in Education, Theory, Reaearch, and Applications. Ohio, New Jersey.

Sergiovanni, Thomas J \& Robert J. Starra. 2002. Supervision : A Redefinition. Sevent Edition. New York: McGraw-Hill.

Soedijarto. 1993. Memantapkan Sistem Pendidikan Nasional.Jakarta: Gramedia Widiasarana Indonesia.

Sondang P. Siagian. 2001. Teori dan Praktek Kepemimpinan. Jakarta: Rineka Cipta.

Suryobroto, Sudibyo. 2003. Psikologi Sosial Pendidikan. Jakarta: Percetakan Solo.

Usman, M. Uzer. 1992. Menjadi Guru Profesional.Bandung : Remaja Rosdakarya.

Usman, Moh. Uzer. 2006. Menjadi Guru Profesional. Bandung: Rosdakarya.

Veron, Waltern M. 2000. Introductory Psycholoty.Ran McNally: Collega Publishing Company.

Winkels W.S. 2000. Psikologi Pendidikan dan Evaluasi Belajar.Jakarta: Gramedia. 